\title{
Nowotwory w Polsce w 2012 roku
}

\author{
Urszula Wojciechowska, Joanna Didkowska
}

\begin{abstract}
Wstęp. Najnowsze dane na temat zagrożenia populacji Polski nowotworami złośliwymi są przedmiotem zainteresowania zarówno instytucji organizujących i finansujących opiekę zdrowotną, jak i lekarzy, naukowców, studentów czy pacjentów. Wychodząc naprzeciw oczekiwaniom, prezentujemy raport "Nowotwory złośliwe w Polsce w 2012", który zawiera informacje dotyczące oczekiwanej liczby zachorowań i zgonów na nowotwory złośliwe w Polsce w 2012 r. Liczby te są oszacowaniem wynikającym z wieloletnich trendów opartych na danych gromadzonych i analizowanych cyklicznie przez zespół Krajowego Rejestru Nowotworów. Raport prezentuje również szeroki zakres informacji na temat zachorowań i zgonów na nowotwory złośliwe w Polsce w 2010 roku (ostatnim roku sprawozdawczym).
\end{abstract}

Materiał i metoda. Dane o zachorowaniach na nowotwory złośliwe pochodzą z Krajowego Rejestru Nowotworów. W niniejszym opracowaniu zastosowano podstawowe wskaźniki statystyczne: liczby bezwzględne, odsetki, współczynniki surowe, współczynniki standaryzowane według wieku na populację świata, życiowe i skumulowane prawdopodobieństwo zachorowania i zgonu na nowotwór.

Wyniki. Najczęściej rozpoznawanymi nowotworami w 2010 r. u mężczyzn był rak płuca (21\%), gruczołu krokowego (13\%) i jelita grubego (12\%). Najczęstszą przyczyną zgonów u mężczyzn był stanowiący ponad 1/3 wszystkich zgonów u mężczyzn rak płuca, wyprzedzający raka jelita grubego (12\%) i gruczoł krokowy (8\%). Z szacunków wynika, że w 2012 roku częstość występowania raka płuca zmniejszyła się (do 20\%), a częstość zachorowań na raka gruczołu krokowego i jelita grubego wzrosła (odpowiednio do 15\% i 13\%), natomiast częstość zgonów z powodu raka płuca, jelita grubego i gruczołu krokowego pozostanie na tym samym poziomie. W populacji kobiet najczęściej diagnozowanym nowotworem w 2010 r. był rak piersi (22\%), wyprzedzając raka jelita grubego (10\%) i płuca (9\%). Pierwszą nowotworową przyczyną zgonów u kobiet, podobnie jak w poprzednich latach, pozostał rak płuca (15\%), przed rakiem piersi (13\%) i jelita grubego (12\%). Oszacowana częstość poszczególnych nowotworów u kobiet w 2012 roku pokazuje, że udział i kolejność wiodących nowotworów wśród zachorowań i zgonów u kobiet nie zmieni się.

Podsumowanie. W ostatnich latach obserwuje się spadek zachorowalności na nowotwory w populacji mężczyzn o 0,2\% rocznie oraz wzrost zachorowalności u kobiet o 1\% rocznie. W przypadku obu płci od końca lat 80 . XX wieku obserwowany jest spadek umieralności, który w ostatnich latach osiąga wartość 1,9\% rocznie u mężczyzn oraz 1,5\% rocznie u kobiet.

Według oszacowań w 2012 roku zachorowało na nowotwory złośliwe w Polsce 145890 osób, a zmarło około 98 500. W ciągu ostatnich 30 lat zarówno liczba zachorowań, jak i zgonów rosła w Polsce liniowo u obu płci. Liczba zachorowań w 2010 roku u mężczyzn i kobiet nie różniła się znacząco (w obu przypadkach przekroczyła 70 0000), natomiast liczba zgonów była wyższa u mężczyzn (blisko 52000 przypadków) niż u kobiet (prawie 41000 przypadków).

\section{Cancer in Poland in 2012}

Introduction. Cancer is an increasing health problem in Poland and the number of cases has been growing steadily during the last three decades. Cancer has now become the second most common cause of death (24\% of deaths in 2010). In this report we present the latest estimates of morbidity and mortality from cancer in Poland in 2012 and also a wide range of information on the occurrence of cancer in 2010 , by gender, age, tumor location and administrative region

Krajowy Rejestr Nowotworów, Zakład Epidemiologii i Prewencji Nowotworów,

Centrum Onkologii — Instytut im. Marii Skłodowskiej-Curie 
of Poland. The report also includes long-term time trends in incidence and mortality which help to assess changes in the risk of cancer in Poland in recent decades.

Material and methods. Data on cancer cases are derived from the National Cancer Registry, and are collected based on a unified protocol for the whole country. This allows us to maintain the same cancer registration rules throughout Poland. The source of data on deaths from cancer is the Central Statistical Office. In this report the basic statistical indicators were used. These are absolute numbers, percentages, crude and age-standardized (ASW) rates, cumulative risk and lifetime risk of developing and dying from cancer. Estimates number of incidence and of deaths for the year 2012 are calculated on the basis of the AP (age-period) model. Annual percentage changes in incidence and mortality trends were analyzed by the Joinpoint Regression Program, allowing up to 3 joinpoints.

Results. A total of 145,890 new cancer cases and 98,500 deaths from cancer are estimated to occur in Poland in 2012. These estimates indicate that the most frequently detected cancer in men in 2012 are lung cancer (20\%), prostate cancer (15\%) and colorectal cancer (13\%). The most common causes of death in men were lung cancer (31\%) and colorectal cancer (12\%). Among women the most commonly diagnosed cancers in 2012 were breast cancer (23\%), colorectal cancer (10\%) and lung cancer (9\%). The most common causes of death among women were lung cancer (15\%), breast cancer (13\%) and colorectal cancer (12\%). In 2010, in Poland, more than 140,500 new cases of cancer were registered and more than 92,500 persons died from cancer. Cancer is the second leading cause of death in Poland, with $26 \%$ of deaths in men and $23 \%$ of deaths among women. Over the past 30 years, both the number of cases and number of deaths in Poland have grown for both sexes. In recent years there has been a decrease in cancer incidence rates in men by $0.2 \%$ per year and an increase in incidence rates in women by $1 \%$ per year. For mortality a decline has been observed of $1.9 \%$ per year in men and $1.5 \%$ per year in women. The most frequently diagnosed cancer in 2010 in men was lung cancer (21\%) followed by prostate cancer (13\%) and colorectal cancer (12\%). The most common causes of death in men were lung cancer (12\%) and prostate cancer ( $8 \%)$. In the female population the most frequently diagnosed cancer in 2010 was breast cancer (22\%), followed by colorectal cancer (10\%) and lung cancer (9\%). The most frequent causes of cancer deaths in women were lung cancer (15\%), breast cancer (13\%) and colorectal cancer (12\%). Analysis of regional differences revealed that the incidence rates in Poland vary (from $209 / 10^{5}$ to $303 / 10^{5}$ in males and from $176 / 10^{5}$ to $249 / 10^{5}$ in females) depending on administrative region. Regional differences are also observed in the level of mortality. In the male population mortality rates range from $151 / 10^{5}$ to $209 / 10^{5}$ and in the female population from $75 / 10^{5}$ to $119 / 10^{5}$.

Summary. This report presents the latest data on incidence and mortality from cancer in 2010 and the estimates for 2012. In comparison to previous years, in 2010 there is still a dominant position for lung cancer in men (both in incidence and mortality), although the incidence is decreasing. In men, there is observed increasing importance of colorectal and prostate cancers. In the population of women in Poland there is observed a growing importance for lung cancer, which is reflected by its dominant position in cancer deaths. In incidence, as in previous years, the most common are breast cancer and colorectal cancer. According to estimates, a significant change in the structure of morbidity and mortality from cancer in 2012 is not expected.

NOWOTWORY Journal of Oncology 2013; 63, 3: 197-216

Słowa kluczowe: nowotwory złośliwe, zachorowalność, umieralność, rejestr nowotworów, trendy czasowe Key words: cancer, incidence, mortality, cancer registry, time trends, lung, prostate, prostate colorectal

\section{Wstęp}

Nowotwory są coraz większym problemem zdrowotnym w Polsce. Liczba zachorowań systematycznie rośnie w ostatnich trzech dekadach, a nowotwory stały się drugą co do częstości przyczyną zgonów, stanowiąc blisko 1/4 zgonów (24\% zgonów w 2010 roku) [1].

W poniższym raporcie prezentujemy najnowsze oszacowanie zachorowań i zgonów na nowotwory złośliwe w Polsce w 2012 roku oraz szeroki zakres informacji o występowaniu chorób nowotworowych w 2010 roku w zależności od płci, wieku, lokalizacji nowotworu czy podziału administracyjnego Polski. Raport zawiera również długoletnie trendy czasowe zachorowań i zgonów pozwalające ocenić zmiany w zagrożeniu nowotworami w naszym kraju w ostatnich dekadach.

\section{Materiał i metody}

Dane o zachorowaniach na nowotwory złośliwe pochodzą z Krajowego Rejestru Nowotworów [1]. Dane gromadzone są w całej Polsce na podstawie tego samego protokołu, którego wzorem jest Karta Zgłoszenia Nowotworu Złośliwego, co pozwala na utrzymanie wspólnego standardu rejestra- 
Tabela I. Szacunkowe liczby zachorowań i zgonów na nowotwory złośliwe w Polsce w 2012 r.*

\begin{tabular}{|c|c|c|c|c|c|c|c|}
\hline & \multirow[t]{2}{*}{ ICD-10 } & \multicolumn{3}{|c|}{ Szacunkowa liczba zachorowań } & \multicolumn{3}{|c|}{ Szacunkowa liczba zgonów } \\
\hline & & Mężczyźni & Kobiety & Ogółem & Mężczyźni & Kobiety & Ogółem \\
\hline Ogółem & $\mathrm{C} 00-\mathrm{C} 96$ & 72820 & 73160 & 145980 & 55250 & 43260 & 98510 \\
\hline Żołądek & $\mathrm{C} 16$ & 3230 & 1660 & 4890 & 3340 & 1810 & 5150 \\
\hline Jelito grube & $\mathrm{C} 81-\mathrm{C} 21$ & 9450 & 7320 & 16770 & 6430 & 5020 & 11450 \\
\hline Krtań & C32 & 1930 & 300 & 2230 & 1440 & 180 & 1620 \\
\hline Płuco & C33-C34 & 14470 & 6350 & 20820 & 17110 & 6350 & 23460 \\
\hline Czerniak skóry & C43 & 1330 & 1440 & 2770 & 685 & 590 & 1275 \\
\hline Pierś & $\mathrm{C} 50$ & & 16850 & 16850 & & 5600 & 5600 \\
\hline Szyjka macicy & C53 & & 3050 & 3050 & & 1720 & 1720 \\
\hline Trzon macicy & C54 & & 5590 & 5590 & & 1030 & 1030 \\
\hline Jajnik & C56 & & 3550 & 3550 & & 2750 & 2750 \\
\hline Gruczoł krokowy & C61 & 10870 & & 10870 & 4440 & & 4440 \\
\hline Nerka & C64 & 2750 & 1870 & 4620 & 1660 & 1030 & 2690 \\
\hline Pęcherz moczowy & C67 & 5020 & 1480 & 6500 & 2670 & 710 & 3380 \\
\hline Chłoniaki nie-Hodgkina & $\mathrm{C} 82-\mathrm{C} 85+\mathrm{C} 96$ & 1550 & 1480 & 3030 & 880 & 790 & 1670 \\
\hline Białaczki & C91-C95 & 1720 & 1400 & 3120 & 1580 & 1320 & 2900 \\
\hline
\end{tabular}

*Oszacowanie oparte na trendzie z lat 1999-2010

cji nowotworów w Polsce. Źródłem danych o zgonach na nowotwory złośliwe jest Główny Urząd Statystyczny, który udostępnia Krajowemu Rejestrowi Nowotworów dane o przypadkach zgonów, które wystąpiły w danym roku w całej populacji.

W niniejszym opracowaniu zastosowano podstawowe wskaźniki statystyczne: liczby bezwzględne, odsetki, współczynniki surowe, współczynniki standaryzowane według wieku na populację świata [2], życiowe i skumulowane prawdopodobieństwo zachorowania i zgonu na nowotwór [3, 4].

Oszacowanie liczby zachorowań i zgonów dla nowotworów złośliwych ogółem oraz 14 najczęstszych nowotworów złośliwych w populacji mężczyzn i kobiet w 2012 roku przygotowane zostało na podstawie modelu AP (age-period) [5]. W obliczeniach wykorzystano rzeczywistą populację Polski dla tych lat opublikowaną przez Główny Urząd Statystyczny [6].

Średnioroczna zmiana w trendach zachorowalności (w latach 1980-2010) i umieralności (w latach 1965-2010) na nowotwory złośliwe w Polsce analizowana była z wykorzystaniem programu Joinpoint Regression (ograniczono do 3 liczbę punktów zmiany) [7].

\section{Wyniki}

\section{Zachorowania i zgony w 2012 roku - oszacowanie}

Precyzyjna liczba zachorowań na nowotwory złośliwe w 2012 roku jest jeszcze nieznana z powodu zróżnicowanej kompletności danych gromadzonych w wojewódzkich rejestrach nowotworowych. Najnowsze rzeczywiste dane o zachorowaniach są dostępne z poślizgiem około 2 lat z po- wodu czasu potrzebnego na zgromadzenie, weryfikację oraz analizę danych [8]. Podobne opóźnienie czasowe występuje w publikacji danych o zgonach przez GUS. W celu oceny bieżącego zagrożenia nowotworami złośliwymi polskiej populacji na podstawie dostępnych danych oszacowano liczbę zachorowań i zgonów na nowotwory złośliwe w 2012 roku.

Według uzyskanych oszacowań oczekiwana liczba nowotworów zdiagnozowanych w 2012 roku wynosi blisko 146000 przypadków w tym około 72820 u mężczyzn i 73160 u kobiet. Szacuje się, że w 2012 roku nowotwory złośliwe są przyczyną 98,5 tysiąca zgonów — ponad 55 tysięcy w populacji mężczyzn i ponad 43 tysiące w populacji kobiet (tab. I).

Nowotwory płuca pozostaną w 2012 roku najczęściej diagnozowanym nowotworem w populacji mężczyzn, stanowiąc 20\% wszystkich zachorowań (blisko 14500 przypadków). Według szacunków kolejnymi wiodącymi nowotworami są: rak gruczołu krokowego z udziałem 15\% (blisko 11000 przypadków), rak jelita grubego zudziałem 13\% (blisko 9500 przypadków) oraz rak pęcherza moczowego, stanowiący 7\% zachorowań (ponad 5000 przypadków) (tab. I, II).

W populacji kobiet, podobnie jak w poprzednich latach, prawie 1/4 zachorowań (23\%, prawie 16900 przypadków) stanowią nowotwory piersi, $10 \%$ — rak jelita grubego (ponad 7300 przypadków), 9\% — rak płuca (prawie 6400 przypadków) oraz 8\% - nowotwory trzonu macicy (blisko 5600 przypadków) (tab. I, II).

Oczekiwana liczba zgonów z powodu nowotworów w 2012 roku szacowana jest na ponad 98500 przypadków. U mężczyzn ponad 17000 (31\%) zgonów powoduje rak płuca, blisko 6500 (12\%) - rak jelita grubego, prawie 
Tabela II. Zachorowania i zgony na najczęstsze nowotwory, szacunkowa częstość występowania w 2012 r.

\begin{tabular}{|c|c|c|c|c|c|}
\hline \multirow[b]{2}{*}{ Ogółem } & \multicolumn{2}{|c|}{ Zachorowania } & \multicolumn{2}{|c|}{ Zgony } & \multirow[b]{2}{*}{ Ogółem } \\
\hline & 72820 & $100 \%$ & $100 \%$ & 55250 & \\
\hline Płuco & 14470 & $20 \%$ & $31 \%$ & 17110 & Płuco \\
\hline Gruczoł krokowy & 10870 & $15 \%$ & $12 \%$ & 6430 & Jelito grube \\
\hline Jelito grube & 9450 & $13 \%$ & $8 \%$ & 4440 & Gruczoł krokowy \\
\hline Pęcherz moczowy & 5020 & $7 \%$ & $6 \%$ & 3340 & Żołądek \\
\hline Żołądek & 3230 & $4 \%$ & $5 \%$ & 2670 & Pęcherz moczowy \\
\hline Nerka & 2750 & $4 \%$ & $3 \%$ & 1660 & Nerka \\
\hline Krtań & 1930 & $3 \%$ & $3 \%$ & 1580 & Białaczki \\
\hline Białaczki & 1720 & $2 \%$ & $3 \%$ & 1440 & Krtań \\
\hline Chłoniaki & 1550 & $2 \%$ & $2 \%$ & 880 & Chłoniaki \\
\hline \multirow[t]{2}{*}{ Czerniak skóry } & 1330 & $2 \%$ & $1 \%$ & 685 & Czerniak skóry \\
\hline & \multicolumn{2}{|c|}{ Zachorowania } & \multicolumn{2}{|c|}{ Zgony } & \\
\hline Ogółem & 73160 & $100 \%$ & $100 \%$ & 43260 & Ogółem \\
\hline Pierś & 16850 & $23 \%$ & $15 \%$ & 6350 & Płuco \\
\hline Jelito grube & 7320 & $10 \%$ & $13 \%$ & 5600 & Pierś \\
\hline Płuco & 6350 & $9 \%$ & $12 \%$ & 5020 & Jelito grube \\
\hline Trzon macicy & 5590 & $8 \%$ & $6 \%$ & 2750 & Jajnik \\
\hline Jajnik & 3550 & $5 \%$ & $4 \%$ & 1810 & Żołądek \\
\hline Szyjka macicy & 3050 & $4 \%$ & $4 \%$ & 1720 & Szyjka macicy \\
\hline Nerka & 1870 & $3 \%$ & $3 \%$ & 1320 & Białaczki \\
\hline Żołądek & 1660 & $2 \%$ & $2 \%$ & 1030 & Trzon macicy \\
\hline Pęcherz moczowy & 1480 & $2 \%$ & $2 \%$ & 1030 & Nerka \\
\hline Chłoniaki & 1480 & $2 \%$ & $2 \%$ & 790 & Chłoniaki \\
\hline Czerniak skóry & 1440 & $2 \%$ & $2 \%$ & 710 & Pęcherz moczowy \\
\hline Białaczki & 1400 & $2 \%$ & $1 \%$ & 590 & Czerniak skóry \\
\hline
\end{tabular}

4500 (12\%) - nowotwór gruczołu krokowego oraz ponad 3300 (6\%) - rak żołądka (tab. I, II).

W populacji kobiet w 2012 roku raka płuca nadal utrzymuje się jako wiodąca przyczyna zgonów nowotworowych. Według szacunków oczekiwana liczba zgonów z tego powodu przekroczy 6300 przypadków (15\%) wyprzedzając nowotwory piersi - 5600 zgonów (13\%), raka jelita grubego — ponad 5000 zgonów (12\%) i nowotwory jajnika — ponad 2700 zgonów (6\%) (tab. I, II).

\section{Zachorowania i zgony w 2010 roku}

W 2010 roku Krajowy Rejestr Nowotworów otrzymał informacje o 70024 pierwszorazowych zgłoszeniach nowotworów złośliwych u mężczyzn i 70540 u kobiet (łącznie 140564 zgłoszenia nowotworów). Standaryzowane współczynniki zachorowalności ogółem w 2010 roku wynosiły $251 / 10^{5}$ u mężczyzn i $205 / 10^{5}$ u kobiet. Na każde 100 tys. osób polskiej populacji przypada 365 zachorowań z powodu nowotworów złośliwych (tab. III).

W 2010 roku wystawiono w Polsce 51817 świadectw zgonów z powodu nowotworów złośliwych u mężczyzn i 40794 u kobiet, łącznie: 92611 aktów zgonu. Poziom standaryzowanych współczynników umieralności ogółem w 2010 roku wynosił 178,3/105 u mężczyzn i 99,4/105 u kobiet. Na każde 100 tys. osób polskiej populacji przypadają 132 zgony z powodu nowotworów złośliwych (tab. IV).

U mężczyzn najwięcej zachorowań notuje się między 55. a 75. rokiem życia. U kobiet najwięcej zachorowań przypada na grupę wieku 50-79 lat. Warto zwrócić uwagę na przewagę liczby zachorowań u młodych i w średnim wieku kobiet w stosunku do mężczyzn. W grupie wiekowej 25-54 lat współczynniki zachorowalności są wyższe u kobiet niż u mężczyzn nawet 1-2 razy. Liczba zgonów jest najwyższa w ósmej dekadzie życia u obu płci, a współczynnik umieralności rośnie wraz wiekiem po 55 roku życia (ryc. 1).

Nowotworami złośliwymi najczęściej rejestrowanymi w 2010 roku u mężczyzn były nowotwory złośliwe płuca - 21,2\%, gruczołu krokowego - 13,2\% i jelita grubego (C18-C21) - 12,4\%. W dalszej kolejności zgłaszane były nowotwory złośliwe pęcherza moczowego - 7,0\% i żołądka - 4,9\%. Standaryzowane współczynniki zachorowalności w 2010 roku wynosiły dla nowotworów złośli- 
Tabela III. Zachorowania na nowotwory złośliwe w Polsce w 2010 r.

\begin{tabular}{|c|c|c|c|c|c|c|c|c|c|c|}
\hline \multirow[t]{2}{*}{ Umiejscowienie } & \multirow[t]{2}{*}{ ICD-10 } & \multicolumn{3}{|c|}{ Mężczyźni } & \multicolumn{3}{|c|}{ Kobiety } & \multicolumn{3}{|c|}{ Ogółem } \\
\hline & & Liczba & $\begin{array}{l}\text { Wsp. } \\
\text { surowy }\end{array}$ & $\begin{array}{l}\text { Wsp. } \\
\text { standary } \\
\text { zowany- }\end{array}$ & Liczba & Wsp. surowy & $\begin{array}{l}\text { Wsp. } \\
\text { standary- } \\
\text { zowany }\end{array}$ & Liczba & $\begin{array}{l}\text { Wsp. } \\
\text { surowy }\end{array}$ & $\begin{array}{l}\text { Wsp. } \\
\text { standary- } \\
\text { zowany }\end{array}$ \\
\hline Ogółem & C00-D09 & 70024 & 375,5 & 251,0 & 70540 & 355,0 & 205,0 & 140564 & 364,9 & 220,8 \\
\hline Jama ustna i gardło: & $\mathrm{C} 00-\mathrm{C} 14$ & 2709 & 14,5 & 9,8 & 960 & 4,8 & 2,8 & 3669 & 9,5 & 6,0 \\
\hline warga & $\mathrm{COO}$ & 318 & 1,7 & 1,1 & 92 & 0,5 & 0,2 & 410 & 1,1 & 0,5 \\
\hline język & $\mathrm{C} 01-\mathrm{C} 02$ & 439 & 2,4 & 1,6 & 161 & 0,8 & 0,5 & 600 & 1,6 & 1,0 \\
\hline gardło & $\mathrm{C} 10-\mathrm{C} 13$ & 662 & 3,6 & 2,5 & 158 & 0,8 & 0,5 & 820 & 2,1 & 1,4 \\
\hline pozostałe & & 1290 & 6,9 & 4,7 & 549 & 2,8 & 1,6 & 1839 & 4,8 & 3,0 \\
\hline Układ trawienny: & $\mathrm{C} 15-\mathrm{C} 26$ & 16157 & 86,6 & 56,5 & 12813 & 64,5 & 32,0 & 28970 & 75,2 & 42,4 \\
\hline przełyk & C15 & 929 & 5,0 & 3,3 & 243 & 1,2 & 0,6 & 1172 & 3,0 & 1,8 \\
\hline żołądek & $\mathrm{C} 16$ & 3399 & 18,2 & 11,9 & 1877 & 9,4 & 4,6 & 5276 & 13,7 & 7,7 \\
\hline jelito cienkie & $\mathrm{C} 17$ & 121 & 0,6 & 0,4 & 120 & 0,6 & 0,3 & 241 & 0,6 & 0,4 \\
\hline okrężnica & C18 & 4819 & 25,8 & 16,6 & 4301 & 21,6 & 10,8 & 9120 & 23,7 & 13,2 \\
\hline odbytnica & $\mathrm{C} 20$ & 3229 & 17,3 & 11,3 & 2267 & 11,4 & 5,8 & 5496 & 14,3 & 8,2 \\
\hline odbyt i kanał odbytu & $\mathrm{C} 21$ & 72 & 0,4 & 0,3 & 160 & 0,8 & 0,4 & 232 & 0,6 & 0,3 \\
\hline jelito grube & C18-C21 & 8685 & 46,6 & 30,2 & 7115 & 35,8 & 18,1 & 15800 & 41,0 & 23,1 \\
\hline $\begin{array}{l}\text { wątroba i przewody } \\
\text { żółciowe }\end{array}$ & $\mathrm{C} 22$ & 829 & 4,4 & 2,9 & 587 & 3,0 & 1,4 & 1416 & 3,7 & 2,1 \\
\hline pęcherzyk żółciowy & $\mathrm{C} 23-\mathrm{C} 24$ & 450 & 2,4 & 1,5 & 1123 & 5,7 & 2,6 & 1573 & 4,1 & 2,2 \\
\hline trzustka & $\mathrm{C} 25$ & 1626 & 8,7 & 5,8 & 1628 & 8,2 & 4,0 & 3254 & 8,4 & 4,8 \\
\hline pozostałe & & 683 & 3,7 & 2,3 & 507 & 2,6 & 1,2 & 1190 & 3,1 & 1,7 \\
\hline Układ oddechowy: & C30-C39 & 17042 & 91,4 & 60,4 & 6516 & 32,8 & 18,3 & 23558 & 61,2 & 36,4 \\
\hline krtań & $\mathrm{C} 32$ & 1924 & 10,3 & 6,9 & 277 & 1,4 & 0,8 & 2201 & 5,7 & 3,6 \\
\hline $\begin{array}{l}\text { tchawica oskrzela } \\
\text { i płuco }\end{array}$ & C33-C34 & 14819 & 79,5 & 52,3 & 6052 & 30,5 & 16,9 & 20871 & 54,2 & 32,1 \\
\hline pozostałe & & 299 & 1,6 & 1,1 & 187 & 0,9 & 0,5 & 486 & 1,3 & 0,8 \\
\hline $\begin{array}{l}\text { Kości i chrząstki } \\
\text { stawowe }\end{array}$ & C40-C41 & 166 & 0,9 & 0,8 & 128 & 0,6 & 0,5 & 294 & 0,8 & 0,7 \\
\hline Nowotwory skóry: & C43-C44 & 5987 & 32,1 & 20,5 & 6611 & 33,3 & 16,7 & 12598 & 32,7 & 18,0 \\
\hline czerniak skóry & C43 & 1195 & 6,4 & 4,4 & 1350 & 6,8 & 4,3 & 2545 & 6,6 & 4,3 \\
\hline inne nowotwory skóry & C44 & 4792 & 25,7 & 16,1 & 5261 & 26,5 & 12,4 & 10053 & 26,1 & 13,8 \\
\hline Tkanki miękkie & C45-C49 & 679 & 3,6 & 2,8 & 555 & 2,8 & 1,9 & 1234 & 3,2 & 2,3 \\
\hline Pierś & C50 & 107 & 0,6 & 0,4 & 15784 & 79,4 & 49,6 & 15891 & 41,3 & 26,7 \\
\hline $\begin{array}{l}\text { Narządy płciowe } \\
\text { żeńskie: }\end{array}$ & C51-C58 & & & & 12541 & 63,1 & 38,2 & 12541 & 63,1 & 38,2 \\
\hline srom i pochwa & C51-C52 & & & & 574 & 2,9 & 1,4 & 574 & 2,9 & 1,4 \\
\hline szyjka macicy & C53 & & & & 3078 & 15,5 & 10,3 & 3078 & 15,5 & 10,3 \\
\hline trzon macicy & C54 & & & & 5125 & 25,8 & 14,8 & 5125 & 25,8 & 14,8 \\
\hline jajnik & C56 & & & & 3587 & 18,1 & 11,3 & 3587 & 18,1 & 11,3 \\
\hline pozostałe & & & & & 177 & 0,9 & 0,4 & 177 & 0,9 & 0,4 \\
\hline $\begin{array}{l}\text { Narządy płciowe } \\
\text { męskie: }\end{array}$ & C60-C63 & 10628 & 57,0 & 38,3 & & & & 10628 & 57,0 & 38,3 \\
\hline prącie & $\mathrm{C} 60$ & 232 & 1,2 & 0,8 & & & & 232 & 1,2 & 0,8 \\
\hline gruczoł krokowy & C61 & 9273 & 49,7 & 32,3 & & & & 9273 & 49,7 & 32,3 \\
\hline jądro & C62 & 1094 & 5,9 & 5,1 & & & & 1094 & 5,9 & 5,1 \\
\hline pozostałe & & 29 & 0,2 & 0,1 & & & & 29 & 0,2 & 0,1 \\
\hline Układ moczowy: & C64-C68 & 7867 & 42,2 & 27,8 & 3420 & 17,2 & 9,3 & 11287 & 29,3 & 17,1 \\
\hline $\begin{array}{l}\text { nerka i miedniczka } \\
\text { nerkowa }\end{array}$ & C64-C65 & 2884 & 15,5 & 10,6 & 1998 & 10,1 & 5,6 & 4882 & 12,7 & 7,8 \\
\hline pęcherz moczowy & C67 & 4919 & 26,4 & 17,0 & 1377 & 6,9 & 3,5 & 6296 & 16,3 & 9,1 \\
\hline pozostałe & & 64 & 0,3 & 0,2 & 45 & 0,2 & 0,1 & 109 & 0,3 & 0,2 \\
\hline Oko & C69 & 128 & 0,7 & 0,5 & 145 & 0,7 & 0,5 & 273 & 0,7 & 0,5 \\
\hline
\end{tabular}


Tabela III. Zachorowania na nowotwory złośliwe w Polsce w 2010 r. (cd.)

\begin{tabular}{|c|c|c|c|c|c|c|c|c|c|c|}
\hline \multirow[t]{2}{*}{ Umiejscowienie } & \multirow[t]{2}{*}{ ICD-10 } & \multicolumn{3}{|c|}{ Mężczyźni } & \multicolumn{3}{|c|}{ Kobiety } & \multicolumn{3}{|c|}{ Ogółem } \\
\hline & & Liczba & $\begin{array}{l}\text { Wsp. } \\
\text { surowy }\end{array}$ & $\begin{array}{l}\text { Wsp. } \\
\text { standary } \\
\text { zowany- }\end{array}$ & Liczba & Wsp. surowy & $\begin{array}{l}\text { Wsp. } \\
\text { standary- } \\
\text { zowany }\end{array}$ & Liczba & $\begin{array}{l}\text { Wsp. } \\
\text { surowy }\end{array}$ & $\begin{array}{l}\text { Wsp. } \\
\text { standary- } \\
\text { zowany }\end{array}$ \\
\hline $\begin{array}{l}\text { Centralny system } \\
\text { nerwowy: }\end{array}$ & C70-C72 & 1479 & 7,9 & 6,1 & 1501 & 7,6 & 5,0 & 2980 & 7,7 & 5,5 \\
\hline mózg & C71 & 1379 & 7,4 & 5,7 & 1353 & 6,8 & 4,6 & 2732 & 7,1 & 5,1 \\
\hline pozostałe & & 100 & 0,5 & 0,4 & 148 & 0,7 & 0,4 & 248 & 0,6 & 0,4 \\
\hline $\begin{array}{l}\text { Gruczoły wydzielania } \\
\text { wewnętrznego: }\end{array}$ & C73-C75 & 457 & 2,5 & 1,9 & 1903 & 9,6 & 7,1 & 2360 & 6,1 & 4,5 \\
\hline tarczyca & $\mathrm{C} 73$ & 384 & 2,1 & 1,5 & 1808 & 9,1 & 6,7 & 2192 & 5,7 & 4,2 \\
\hline pozostałe & & 73 & 0,4 & 0,3 & 95 & 0,5 & 0,4 & 168 & 0,4 & 0,3 \\
\hline $\begin{array}{l}\text { Nowotwory } \\
\text { niedokładnie } \\
\text { określone i wtórne }\end{array}$ & C76-C80 & 2168 & 11,6 & 7,5 & 2020 & 10,2 & 4,6 & 4188 & 10,9 & 5,9 \\
\hline $\begin{array}{l}\text { Tkanka limfatyczna } \\
\text { i krwiotwórcza: }\end{array}$ & C81-C96 & 3970 & 21,3 & 16,0 & 3783 & 19,0 & 11,8 & 7753 & 20,1 & 13,7 \\
\hline choroba Hodgkina & C81 & 343 & 1,8 & 1,6 & 363 & 1,8 & 1,7 & 706 & 1,8 & 1,6 \\
\hline $\begin{array}{l}\text { chłoniaki nie- } \\
\text { Hodgkina }\end{array}$ & C82-C85 & 1417 & 7,6 & 5,3 & 1320 & 6,6 & 3,8 & 2737 & 7,1 & 4,5 \\
\hline $\begin{array}{l}\text { choroby } \\
\text { immunoproliferacyjne }\end{array}$ & $\mathrm{C} 88$ & 32 & 0,2 & 0,1 & 19 & 0,1 & 0,0 & 51 & 0,1 & 0,1 \\
\hline szpiczak mnogi & $\mathrm{C} 90$ & 570 & 3,1 & 2,0 & 677 & 3,4 & 1,7 & 1247 & 3,2 & 1,8 \\
\hline białaczka limfatyczna & C91 & 904 & 4,8 & 4,1 & 710 & 3,6 & 2,4 & 1614 & 4,2 & 3,2 \\
\hline białaczka szpikowa & C92 & 544 & 2,9 & 2,2 & 516 & 2,6 & 1,6 & 1060 & 2,8 & 1,8 \\
\hline wszystkie białaczki & C91-C95 & 1573 & 8,4 & 6,8 & 1357 & 6,8 & 4,4 & 2930 & 7,6 & 5,5 \\
\hline $\begin{array}{l}\text { inny i nieokreślony } \\
\text { nowotwór tkanki } \\
\text { limfatycznej } \\
\text { i krwiotwórczej }\end{array}$ & C96 & 35 & 0,2 & 0,2 & 47 & 0,2 & 0,2 & 82 & 0,2 & 0,2 \\
\hline $\begin{array}{l}\text { Nowotwory złośliwe } \\
\text { pierwotnych mnogich } \\
\text { umiejscowień }\end{array}$ & C97 & 3 & 0,0 & 0,0 & 0 & 0,0 & 0,0 & 3 & 0,0 & 0,0 \\
\hline Nowotwory in situ & D00-D09 & 477 & 2,6 & 1,7 & 1860 & 9,4 & 6,7 & 2337 & 6,1 & 4,2 \\
\hline
\end{tabular}

wych płuca $52,3 / 10^{5}$, nowotworów złośliwych gruczołu krokowego - 32,3/10 , nowotworów złośliwych jelita grubego - 30,2/105, nowotworów złośliwych pęcherza moczowego - 17,0/105 i nowotworów złośliwych żołądka $-11,9 / 10^{5}$ (tab. III, ryc. 2).

U kobiet w 2010 r. najczęściej rejestrowany byłnowotwór złośliwy piersi - 22,4\%, jelita grubego - 10,1\%, a następnie płuca $-8,6 \%$, trzonu macicy - 7,3\%, jajnika $-5,1 \%$ i szyjki macicy $-4,4 \%$ (ryc. 2). Zachorowalność na nowotwory złośliwe piersi w 2010 roku wynosiła 49,6/105, na nowotwory złośliwe jelita grubego - 18,1/10 $0^{5}$, na nowotwory złośliwe płuca $-16,9 / 10^{5}$, na nowotwory złośliwe trzonu macicy $-14,8 / 10^{5}$, na nowotwory złośliwe jajnika $-11,3 / 10^{5}$ oraz nowotwory złośliwe szyjki macicy - 10,3/10 (tab. III, ryc. 2).

U mężczyzn w 2010 roku największy odsetek zgonów nowotworowych stanowiły zgony z powodu nowotworów złośliwych płuca (31,3\%), jelita grubego (C18-C21 11,5\%), gruczołu krokowego (7,6\%), w dalszej kolejności znajdowały się nowotwory złośliwe żołądka $(6,7 \%)$ oraz pęcherza moczowego (4,8\%). Standaryzowane współczynniki umieralno- ści wśród mężczyzn w Polsce wynosiły dla nowotworów złośliwych płuca $56,2 / 10^{5}$, jelita grubego (okrężnica, odbytnica i odbyt) $-20 / 10^{5}$, gruczołu krokowego $-12,4 / 10^{5}$, żołądka $-11,8 / 10^{5}$ i pęcherza moczowego $-8,4 / 10^{5}$ (tab. IV, ryc. 2).

Wśród kobiet w 2010 roku po raz kolejny największy odsetek zgonów nowotworowych stanowiły zgony z powodu raka płuca $(15,1 \%)$, drugą pozycję zajmowały nowotwory złośliwe piersi (12,8\%), a w następnej kolejności znajdowały się nowotwory jelita grubego (C18-C21 11,9\%), jajnika $(6,2 \%)$, trzustki $(5,5 \%)$, żołądka $(4,6 \%)$ i szyjki macicy (4,3\%). Standaryzowane współczynniki umieralności wynosiły w przypadku raka płuca $16,3 / 10^{5}$, nowotworów piersi $-13,7 / 10^{5}$, jelita grubego $-10,4 / 10^{5}$, jajnika $-7,0 / 10^{5}$, szyjki macicy $-5,1 / 10^{5}$, trzustki $-5,1 / 10^{5}$ oraz żołądka $-4,2 / 10^{5}$ (tab. IV, ryc. 2).

W ciągu ostatnich trzech dekad liczba zachorowań i zgonów gwałtownie rosła: wśród mężczyzn nastąpił wzrost o prawie 36 tys. zachorowań; wśród kobiet o prawie 40 tys. zachorowań, co oznacza, że liczba zachorowań wzrosła u obu płci około dwukrotnie. 
Tabela IV. Zgony na nowotwory złośliwe w Polsce w 2010 r.

\begin{tabular}{|c|c|c|c|c|c|c|c|c|c|c|}
\hline \multirow[t]{2}{*}{ Umiejscowienie } & \multirow[t]{2}{*}{ ICD-10 } & \multicolumn{3}{|c|}{ Mężczyźni } & \multicolumn{3}{|c|}{ Kobiety } & \multicolumn{3}{|c|}{ Ogółem } \\
\hline & & Liczba & $\begin{array}{l}\text { Wsp. } \\
\text { surowy }\end{array}$ & $\begin{array}{c}\text { Wsp. } \\
\text { standary- } \\
\text { zowany }\end{array}$ & Liczba & $\begin{array}{l}\text { Wsp. } \\
\text { surowy }\end{array}$ & $\begin{array}{c}\text { Wsp. } \\
\text { standary- } \\
\text { zowany }\end{array}$ & Liczba & $\begin{array}{l}\text { Wsp. } \\
\text { surowy }\end{array}$ & $\begin{array}{c}\text { Wsp. } \\
\text { standary- } \\
\text { zowany }\end{array}$ \\
\hline Ogółem & C00-D09 & 51817 & 277,9 & 178,3 & 40794 & 205,3 & 99,4 & 92611 & 240,4 & 131,6 \\
\hline Jama ustna i gardło: & $\mathrm{C} 00-\mathrm{C} 14$ & 1763 & 0,4 & 6,3 & 464 & 2,3 & 1,2 & 2227 & 5,8 & 3,5 \\
\hline warga & $\mathrm{COO}$ & 81 & 1,9 & 0,3 & 24 & 0,1 & 0,0 & 105 & 0,3 & 0,1 \\
\hline język & $\mathrm{C} 01-\mathrm{C} 02$ & 347 & 2,0 & 1,3 & 85 & 0,4 & 0,2 & 432 & 1,1 & 0,7 \\
\hline gardło & $\mathrm{C} 10-\mathrm{C} 13$ & 378 & 5,1 & 1,4 & 65 & 0,3 & 0,2 & 443 & 1,2 & 0,7 \\
\hline pozostałe & & 957 & 79,3 & 3,4 & 290 & 1,5 & 0,8 & 1247 & 3,2 & 2,0 \\
\hline Układ trawienny: & C15-C26 & 14787 & 5,9 & 50,5 & 12125 & 61,0 & 26,6 & 26912 & 69,9 & 36,7 \\
\hline przełyk & $\mathrm{C} 15$ & 1106 & 18,7 & 3,9 & 290 & 1,5 & 0,7 & 1396 & 3,6 & 2,1 \\
\hline żołądek & $\mathrm{C} 16$ & 3486 & 0,3 & 11,8 & 1878 & 9,5 & 4,2 & 5364 & 13,9 & 7,4 \\
\hline jelito cienkie & C17 & 64 & 20,2 & 0,2 & 75 & 0,4 & 0,2 & 139 & 0,4 & 0,2 \\
\hline okrężnica & C18 & 3768 & 9,9 & 12,6 & 3293 & 16,6 & 7,1 & 7061 & 18,3 & 9,3 \\
\hline odbytnica & $\mathrm{C} 20$ & 1852 & 0,9 & 6,3 & 1277 & 6,4 & 2,7 & 3129 & 8,1 & 4,2 \\
\hline odbyt i kanał odbytu & $\mathrm{C} 21$ & 163 & 32,0 & 0,6 & 149 & 0,7 & 0,3 & 312 & 0,8 & 0,4 \\
\hline jelito grube & $\mathrm{C} 18-\mathrm{C} 21$ & 5959 & 5,7 & 20,0 & 4861 & 24,5 & 10,4 & 10820 & 28,1 & 14,3 \\
\hline $\begin{array}{l}\text { wątroba i przewody } \\
\text { żółciowe }\end{array}$ & C22 & 1058 & 2,8 & 3,7 & 957 & 4,8 & 2,1 & 2015 & 5,2 & 2,8 \\
\hline pęcherzyk żółciowy & C23-C24 & 518 & 12,2 & 1,7 & 1384 & 7,0 & 3,0 & 1902 & 4,9 & 2,5 \\
\hline trzustka & $\mathrm{C} 25$ & 2280 & 2,6 & 8,1 & 2250 & 11,3 & 5,1 & 4530 & 11,8 & 6,4 \\
\hline pozostałe & & 492 & 96,2 & 1,6 & 572 & 2,9 & 1,2 & 1064 & 2,8 & 1,4 \\
\hline Układ oddechowy: & C30-C39 & 17937 & 7,3 & 62,3 & 6555 & 33,0 & 17,3 & 24492 & 63,6 & 36,4 \\
\hline krtań & C32 & 1358 & 86,9 & 4,8 & 169 & 0,9 & 0,5 & 1527 & 4,0 & 2,4 \\
\hline $\begin{array}{l}\text { tchawica oskrzela } \\
\text { i płuco }\end{array}$ & C33-C34 & 16204 & 2,0 & 56,2 & 6170 & 31,1 & 16,3 & 22374 & 58,1 & 33,2 \\
\hline pozostałe & & 375 & 1,1 & 1,3 & 216 & 1,1 & 0,5 & 591 & 1,5 & 0,9 \\
\hline $\begin{array}{l}\text { Kości i chrząstki } \\
\text { stawowe }\end{array}$ & C40-C41 & 199 & 4,0 & 0,8 & 126 & 0,6 & 0,4 & 325 & 0,8 & 0,6 \\
\hline Nowotwory skóry: & C43-C44 & 751 & 3,3 & 2,6 & 735 & 3,7 & 1,7 & 1486 & 3,9 & 2,1 \\
\hline czerniak skóry & C43 & 621 & 0,7 & 2,2 & 570 & 2,9 & 1,4 & 1191 & 3,1 & 1,8 \\
\hline inne nowotwory skóry & $\mathrm{C} 44$ & 130 & 2,2 & 0,4 & 165 & 0,8 & 0,3 & 295 & 0,8 & 0,3 \\
\hline Tkanki miękkie & C45-C49 & 415 & 0,3 & 1,6 & 324 & 1,6 & 0,9 & 739 & 1,9 & 1,2 \\
\hline Pierś & C50 & 59 & 0,0 & 0,2 & 5226 & 26,3 & 13,7 & 5285 & 13,7 & 7,7 \\
\hline Narządy płciowe żeńskie: & C51-C58 & & & & 6193 & 31,2 & 16,5 & 6193 & 31,2 & 16,5 \\
\hline srom i pochwa & C51-C52 & & & & 318 & 1,6 & 0,7 & 318 & 1,6 & 0,7 \\
\hline szyjka macicy & C53 & & & & 1735 & 8,7 & 5,1 & 1735 & 8,7 & 5,1 \\
\hline trzon macicy & C54 & & & & 1042 & 5,2 & 2,5 & 1042 & 5,2 & 2,5 \\
\hline jajnik & C56 & & & & 2547 & 12,8 & 7,0 & 2547 & 12,8 & 7,0 \\
\hline pozostałe & & & & & 551 & 2,8 & 1,2 & 551 & 2,8 & 1,2 \\
\hline $\begin{array}{l}\text { Narządy płciowe } \\
\text { męskie: }\end{array}$ & $\mathrm{C} 60-\mathrm{C} 63$ & 4169 & 0,5 & 13,2 & & & & 4169 & 0,5 & 13,2 \\
\hline prącie & $\mathrm{C} 60$ & 89 & 21,1 & 0,3 & & & & 89 & 21,1 & 0,3 \\
\hline gruczoł krokowy & C61 & 3940 & 0,7 & 12,4 & & & & 3940 & 0,7 & 12,4 \\
\hline jądro & C62 & 123 & 0,1 & 0,5 & & & & 123 & 0,1 & 0,5 \\
\hline pozostałe & & 17 & 22,1 & 0,1 & & & & 17 & 22,1 & 0,1 \\
\hline Układ moczowy: & C64-C68 & 4116 & 8,6 & 13,8 & 1638 & 8,2 & 3,5 & 5754 & 14,9 & 7,7 \\
\hline $\begin{array}{l}\text { nerka i miedniczka } \\
\text { nerkowa }\end{array}$ & C64-C65 & 1601 & 13,2 & 5,5 & 970 & 4,9 & 2,2 & 2571 & 6,7 & 3,6 \\
\hline pęcherz moczowy & $\mathrm{C} 67$ & 2470 & 0,2 & 8,1 & 641 & 3,2 & 1,3 & 3111 & 8,1 & 4,0 \\
\hline pozostałe & & 45 & 0,2 & 0,2 & 27 & 0,1 & 0,1 & 72 & 0,2 & 0,1 \\
\hline
\end{tabular}


Tabela IV. Zgony na nowotwory złośliwe w Polsce w 2010 r. (cd.)

\begin{tabular}{|c|c|c|c|c|c|c|c|c|c|c|}
\hline \multirow[t]{2}{*}{ Umiejscowienie } & \multirow[t]{2}{*}{ ICD-10 } & \multicolumn{3}{|c|}{ Mężczyźni } & \multicolumn{3}{|c|}{ Kobiety } & \multicolumn{3}{|c|}{ Ogółem } \\
\hline & & Liczba & $\begin{array}{l}\text { Wsp. } \\
\text { surowy }\end{array}$ & $\begin{array}{l}\text { Wsp. } \\
\text { standary- } \\
\text { zowany }\end{array}$ & Liczba & $\begin{array}{l}\text { Wsp. } \\
\text { surowy }\end{array}$ & $\begin{array}{l}\text { Wsp. } \\
\text { standary- } \\
\text { zowany }\end{array}$ & Liczba & $\begin{array}{l}\text { Wsp. } \\
\text { surowy }\end{array}$ & $\begin{array}{l}\text { Wsp. } \\
\text { standary- } \\
\text { zowany }\end{array}$ \\
\hline Oko & C69 & 37 & 7,9 & 0,1 & 46 & 0,2 & 0,1 & 83 & 0,2 & 0,1 \\
\hline $\begin{array}{l}\text { Centralny system } \\
\text { nerwowy: }\end{array}$ & $\mathrm{C} 70-\mathrm{C} 72$ & 1474 & 7,6 & 5,7 & 1480 & 7,4 & 4,2 & 2954 & 7,7 & 4,9 \\
\hline mózg & $\mathrm{C} 71$ & 1413 & 0,3 & 5,4 & 1412 & 7,1 & 4,1 & 2825 & 7,3 & 4,7 \\
\hline pozostałe & & 61 & 0,8 & 0,2 & 68 & 0,3 & 0,2 & 129 & 0,3 & 0,2 \\
\hline $\begin{array}{l}\text { Gruczoły wydzielania } \\
\text { wewnętrznego: }\end{array}$ & C73-C75 & 140 & 0,4 & 0,5 & 254 & 1,3 & 0,6 & 394 & 1,0 & 0,6 \\
\hline tarczyca & $\mathrm{C} 73$ & 74 & 0,4 & 0,3 & 187 & 0,9 & 0,4 & 261 & 0,7 & 0,3 \\
\hline pozostałe & & 66 & 16,4 & 0,2 & 67 & 0,3 & 0,2 & 133 & 0,3 & 0,2 \\
\hline $\begin{array}{l}\text { Nowotwory } \\
\text { niedokładnie określone } \\
\text { i wtórne }\end{array}$ & C76-C80 & 3058 & 15,4 & 10,3 & 2959 & 14,9 & 6,3 & 6017 & 15,6 & 7,9 \\
\hline $\begin{array}{l}\text { Tkanka limfatyczna } \\
\text { i krwiotwórcza: }\end{array}$ & C81-C96 & 2879 & 0,6 & 10,2 & 2629 & 13,2 & 6,3 & 5508 & 14,3 & 8,0 \\
\hline choroba Hodgkina & $\mathrm{C} 81$ & 111 & 4,0 & 0,5 & 78 & 0,4 & 0,3 & 189 & 0,5 & 0,4 \\
\hline chłoniaki nie-Hodgkina & $\mathrm{C} 82-\mathrm{C} 85$ & 746 & 0,2 & 2,6 & 662 & 3,3 & 1,7 & 1408 & 3,7 & 2,1 \\
\hline $\begin{array}{l}\text { choroby } \\
\text { immunoproliferacyjne }\end{array}$ & C88 & 30 & 2,7 & 0,1 & 27 & 0,1 & 0,1 & 57 & 0,1 & 0,1 \\
\hline szpiczak mnogi & $\mathrm{C} 90$ & 512 & 3,7 & 1,7 & 611 & 3,1 & 1,3 & 1123 & 2,9 & 1,5 \\
\hline białaczka limfatyczna & C91 & 689 & 3,3 & 2,5 & 527 & 2,7 & 1,2 & 1216 & 3,2 & 1,8 \\
\hline białaczka szpikowa & $\mathrm{C} 92$ & 623 & 7,7 & 2,2 & 574 & 2,9 & 1,5 & 1197 & 3,1 & 1,8 \\
\hline wszystkie białaczki & C91-C95 & 1431 & 0,3 & 5,1 & 1211 & 6,1 & 2,9 & 2642 & 6,9 & 3,9 \\
\hline $\begin{array}{l}\text { inny i nieokreślony } \\
\text { nowotwór tkanki } \\
\text { limfatycznej } \\
\text { i krwiotwórczej }\end{array}$ & C96 & 49 & 0,2 & 0,2 & 40 & 0,2 & 0,1 & 89 & 0,2 & 0,1 \\
\hline $\begin{array}{l}\text { Nowotwory złośliwe } \\
\text { pierwotnych mnogich } \\
\text { umiejscowień }\end{array}$ & $\mathrm{C} 97$ & 32 & 0,0 & 0,1 & 40 & 0,2 & 0,1 & 72 & 0,2 & 0,1 \\
\hline
\end{tabular}

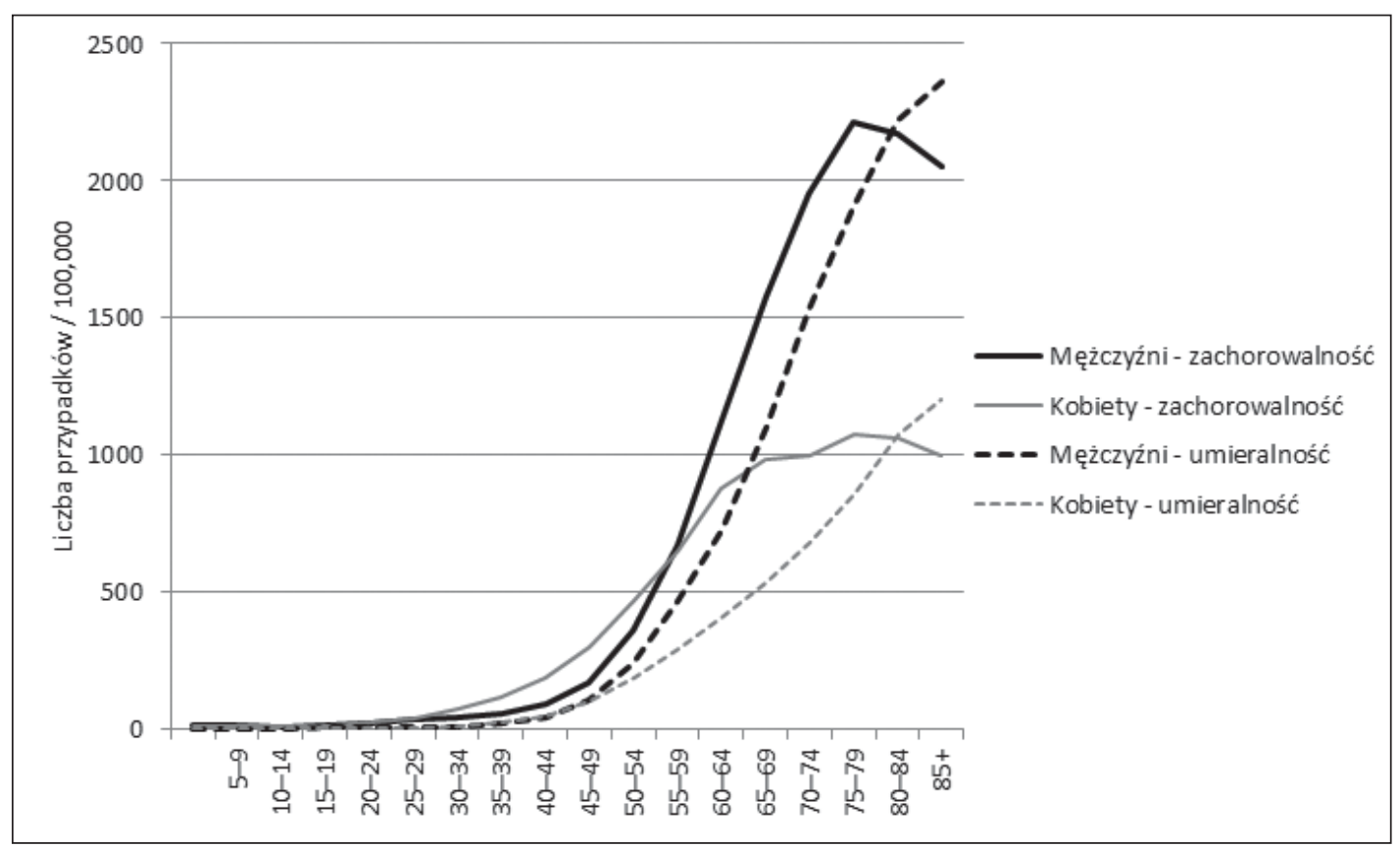

Rycina 1. Zachorowalność i umieralność na nowotwory złośliwe w Polsce w 2010 r. w zależności od płci i wieku 


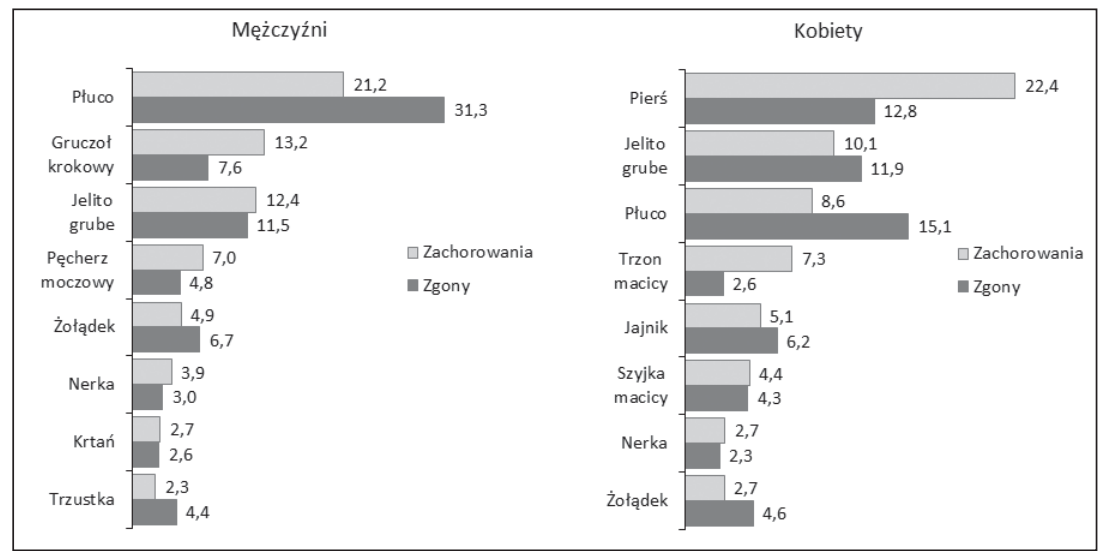

Rycina 2. Zachorowania i zgony na najczęstsze nowotwory, częstość występowania w 2010 r. w zależności od płci

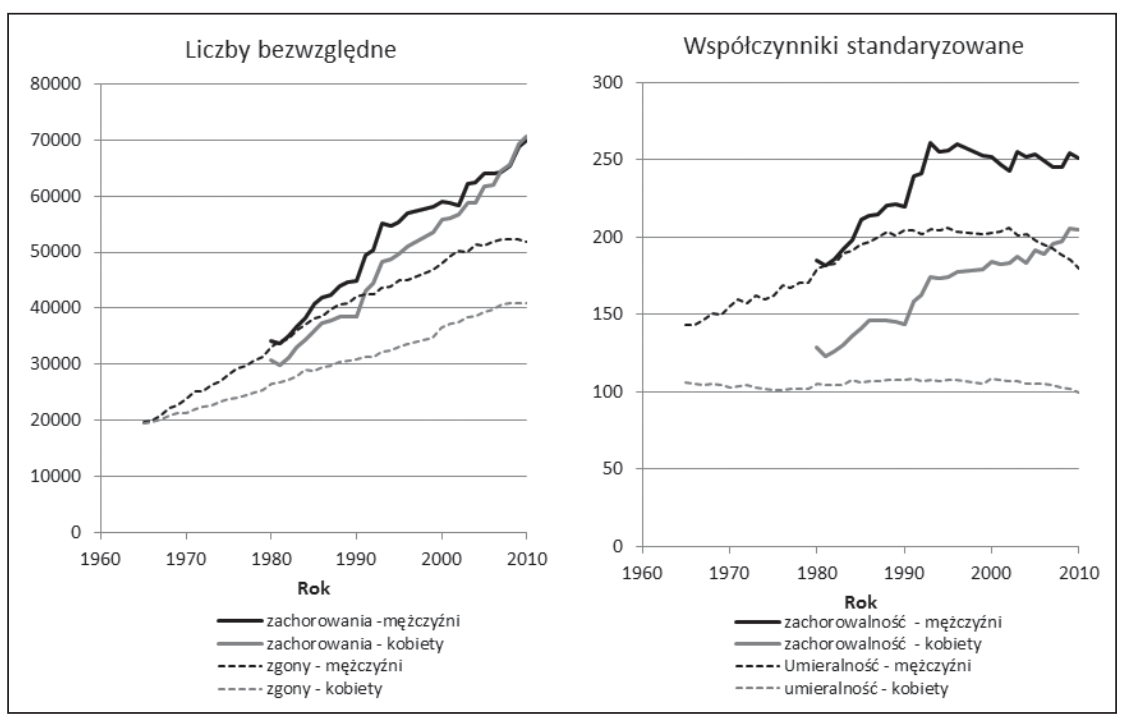

Rycina 3. Trendy zachorowalności i umieralności na nowotwory złośliwe w Polsce w latach 1965-2010

Wzrostowi zachorowań towarzyszył także wzrost liczby zgonów nowotworowych (w analogicznym okresie o prawie 19 tys. wśród mężczyzn i ponad 14 tys. wśród kobiet), chociaż jeśli chodzi o mężczyzn, to początek lat 90. przyniósł zmniejszenie tempa wzrostu współczynników umieralności, a od początku XXI wieku — zauważalny spadek (ryc. 3). Wzrost zagrożenia nowotworami w Polsce w ostatnich 40 latach można przypisać przede wszystkim zmianom struktury wieku populacji [1].

Zmiany zachorowalności na nowotwory złośliwe aż do połowy lat 80 . były związane w znacznym stopniu z poprawą kompletności rejestracji $[9,10]$. W populacji mężczyzn od początku lat 80 . do początku lat 90 . utrzymywała się rosnąca tendencja zachorowalności, po czym nastąpiło zahamowanie, i w ostatniej dekadzie utrzymuje się plateau. W populacji kobiet zachorowalność nadal wzrasta (ryc. 3).

Umieralność z powodu nowotworów złośliwych ogółem wśród mężczyzn powiela trendy charakterystyczne dla zachorowalności (co wynika z wyjątkowo dużego udziału jednej lokalizacji — raka płuca). Wśród kobiet w ciągu ostat- nich czterech dekad umieralność utrzymywała się na stałym poziomie (ryc. 3).

W populacji polskich mężczyzn w drugiej połowie XX wieku najszybciej rosło zagrożenie rakiem płuca i to on zdominował obraz nowotworów u mężczyzn. W ostatnich dwóch dekadach wzrost ten (zarówno w przypadku zachorowań, jak i zgonów) został zahamowany i odwrócony (zmniejszenie częstości palenia papierosów [11]). Zachorowania i umieralność z powodu raka płuca u dorosłych młodych i w średnim wieku spadły o 30\% [12]. W latach 90. XX wieku i w początku XXI wieku schorzeniem o największej dynamice wzrostu zachorowalności i drugim co do częstości występowania jest nowotwór jelita grubego. Kolejnym schorzeniem nowotworowym u mężczyzn jest nowotwór gruczołu krokowego, którego przyspieszenie tempa wzrostu zachorowalności obserwuje się w ostatniej dekadzie [13], co spowodowało, że nowotwory te w 2007 roku po raz pierwszy wyprzedziły nowotwory jelita grubego. Warto zwrócić uwagę, że czwarty pod względem częstości występowania, rakżołądka, którego spadek zachorowalności i umieralności stale obserwuje się 


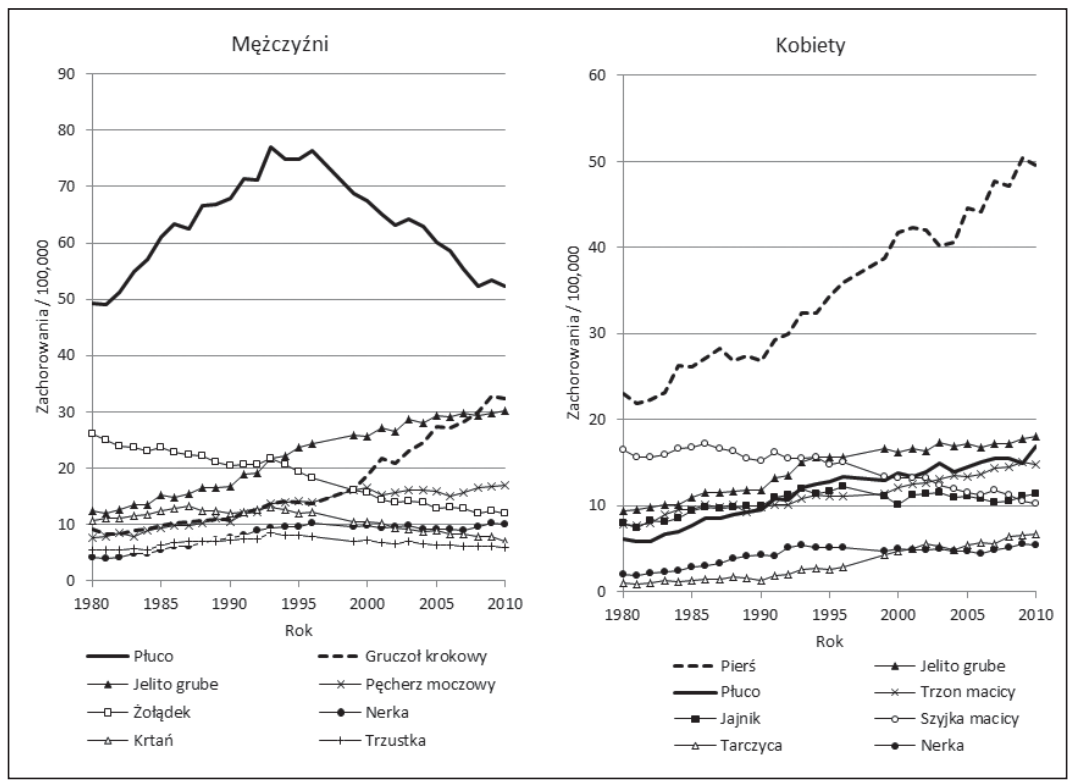

Rycina 4. Trendy zachorowalności na najczęstsze nowotwory złośliwe u w Polsce w latach 1980-2010

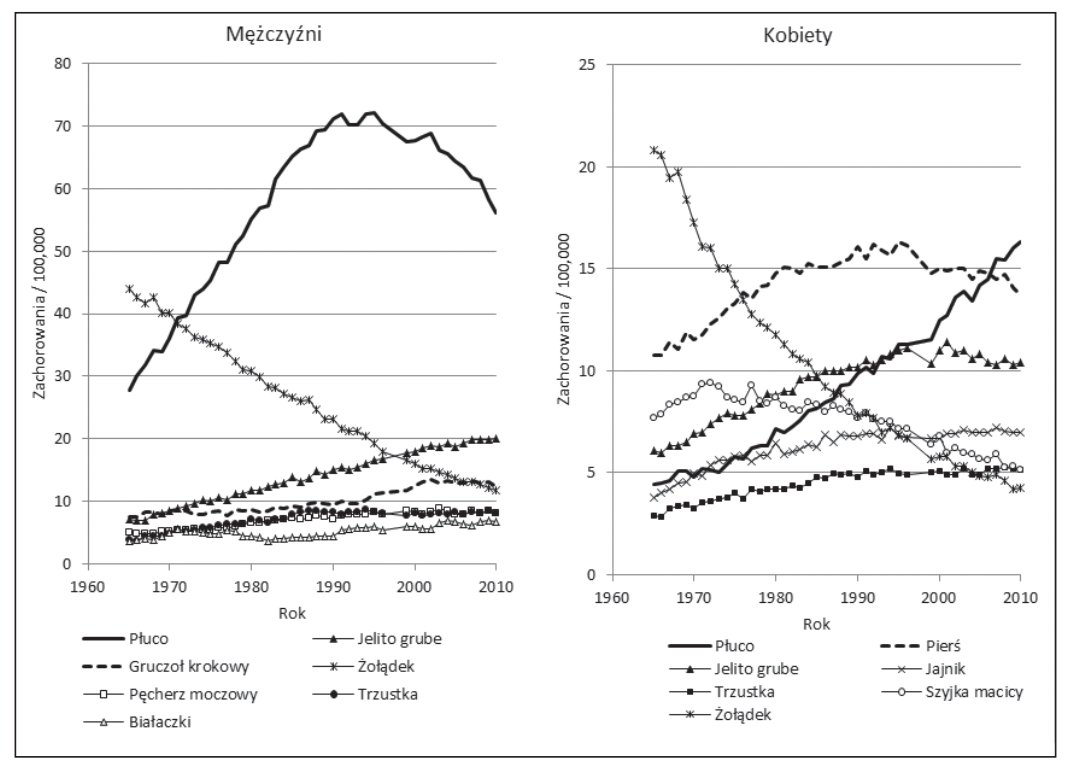

Rycina 5. Trendy umieralności na najczęstsze nowotwory złośliwe u w Polsce w latach 1980-2010

przez ostatnie pół wieku, jest jedyną lokalizacją u mężczyzn o długoletniej tendencji spadkowej (ryc. 4, 5).

W populacji kobiet najczęstszą nowotworową przyczyną zgonów od połowy lat 70. były nowotwory piersi, chociaż od początku lat 80. nastąpiła stabilizacja umieralności, przy stale utrzymującym się wzroście zachorowalności [13], a ostatnia dekada przyniosła nawet niewielki spadek umieralności, który w połączeniu z gwałtownym przyrostem zachorowań izgonów z powodu raka płuca spowodował, że od 2007 roku rak piersi jest drugą nowotworową przyczyną zgonu. Obserwowany w ostatnich dwóch dekadach szybki przyrost liczby zgonów z powodu nowotworów złośliwych płuca sprawił, że frakcja nowotworów płuca przekroczyła frakcję nowotworów piersi i rak płuca stał się po raz kolejny główną nowotworową przyczyną zgonów u kobiet. Po okresie szybkiego wzrostu umieralności z powodu raka jelita grubego od początku XXI wieku rozpoczęła się wyraźna tendencja spadkowa przy utrzymującym się wzroście zachorowalności. Czwarty co do częstości zachorowań nowotwór trzonu macicy charakteryzuje się rosnącym trendem zachorowalności (ryc. 5) i stabilną od kilku dekad niską umieralnością [14]. Zachorowalność i umieralność z powodu nowotworów żołądka wykazuje systematyczny spadek, stając się z najczęstszego nowotworu jeszcze w połowie lat 70. nowotworem rzadkim (4-krotny spadek umieralności). Zachorowalność i umieralność z powodu raka szyjki macicy wykazuje od połowy siódmej dekady ubiegłego wieku tendencję malejącą (ryc. 4, 5). 
Tabela V. Zachorowania na 5 najczęstszych nowotworów w Polsce w 2010 r. w zależności od płci i wieku

\begin{tabular}{|c|c|c|c|c|c|c|c|c|c|}
\hline \multicolumn{10}{|c|}{ Mężczyźni } \\
\hline \multicolumn{2}{|c|}{$0+$} & \multicolumn{2}{|c|}{ 0-19 } & \multicolumn{2}{|c|}{$20-44$} & \multicolumn{2}{|c|}{$45-64$} & \multicolumn{2}{|c|}{$65+$} \\
\hline liczba & wsp. stand. & liczba & wsp. stand. & liczba & wsp. stand. & liczba & wsp. stand. & liczba & wsp. stand. \\
\hline \multicolumn{2}{|c|}{$\begin{array}{l}\text { Nowotwory } \\
\text { ogółem }\end{array}$} & \multicolumn{2}{|c|}{$\begin{array}{c}\text { Nowotwory } \\
\text { ogółem }\end{array}$} & \multicolumn{2}{|c|}{$\begin{array}{c}\text { Nowotwory } \\
\text { ogółem }\end{array}$} & \multicolumn{2}{|c|}{$\begin{array}{c}\text { Nowotwory } \\
\text { ogółem }\end{array}$} & \multicolumn{2}{|c|}{$\begin{array}{c}\text { Nowotwory } \\
\text { ogółem }\end{array}$} \\
\hline \multicolumn{2}{|c|}{70024} & \multicolumn{2}{|r|}{$0,8 \%$} & \multicolumn{2}{|l|}{3457} & \multicolumn{2}{|l|}{28282} & 37722 & $54 \%$ \\
\hline \multicolumn{2}{|c|}{ Płuco } & \multicolumn{2}{|c|}{ Białaczki } & \multicolumn{2}{|c|}{ Jądro } & \multicolumn{2}{|c|}{ Płuco } & \multicolumn{2}{|c|}{ Płuco } \\
\hline \multicolumn{2}{|c|}{$14819 \quad 21 \%$} & \multicolumn{2}{|c|}{176} & \multicolumn{2}{|l|}{870} & \multicolumn{2}{|l|}{6799} & \multicolumn{2}{|l|}{7846} \\
\hline \multicolumn{2}{|c|}{ Gruczoł krokowy } & \multicolumn{2}{|c|}{ Mózg i CUN } & & grube & Jel & grube & Grucz & krokowy \\
\hline 9273 & $13 \%$ & 98 & $17 \%$ & 246 & $7 \%$ & 3280 & $12 \%$ & 6605 & $18 \%$ \\
\hline Jeli & grube & Tka & niękkie & & CUN & Grucz & krokowy & Jeli & grube \\
\hline 8685 & $12 \%$ & 55 & $10 \%$ & 238 & $7 \%$ & 2660 & $9 \%$ & 5159 & $14 \%$ \\
\hline Pęche & noczowy & & & & niak & Pęche & noczowy & Pęche & noczowy \\
\hline 4919 & $7 \%$ & 52 & $9 \%$ & 205 & $6 \%$ & 1699 & $6 \%$ & 3119 & $8 \%$ \\
\hline & dek & & niaki & Chłor & Hodkina & & & & dek \\
\hline 3399 & $5 \%$ & 42 & $7 \%$ & 180 & $5 \%$ & 1394 & $5 \%$ & 1921 & $5 \%$ \\
\hline & & & & & ety & & & & \\
\hline & & & & & & & 64 & & + \\
\hline liczba & wsp. stand. & liczba & wsp. stand. & liczba & wsp. stand. & liczba & wsp. stand. & liczba & wsp. stand. \\
\hline $\begin{array}{r}\text { Nol } \\
0\end{array}$ & $\begin{array}{l}\text { twory } \\
\text { tem }\end{array}$ & & $\begin{array}{l}\text { twory } \\
\text { tem }\end{array}$ & & $\begin{array}{l}\text { wory } \\
\text { em }\end{array}$ & $\begin{array}{r}\text { No } \\
0\end{array}$ & $\begin{array}{l}\text { twory } \\
\text { tem }\end{array}$ & $\begin{array}{r}\text { No } \\
0\end{array}$ & $\begin{array}{l}\text { twory } \\
\text { tem }\end{array}$ \\
\hline & 540 & 440 & $0,6 \%$ & 5802 & $8 \%$ & 31273 & $44 \%$ & 33025 & $47 \%$ \\
\hline & & & czki & & & & & & \\
\hline 15784 & $22 \%$ & 116 & $26 \%$ & 1565 & $27 \%$ & 8869 & $28 \%$ & 5350 & $16 \%$ \\
\hline Jeli & grube & & i CUN & $\begin{array}{l}\text { Szy } \\
\text { (w }\end{array}$ & $\begin{array}{l}\text { nacicy } \\
\text { in situ) }\end{array}$ & & & Jeli & grube \\
\hline 7115 & $10 \%$ & 78 & $18 \%$ & 983 & $17 \%$ & 3071 & $10 \%$ & 4447 & $13 \%$ \\
\hline & & Chłon & Hodgkina & & yca & Trzc & nacicy & & \\
\hline 6052 & $9 \%$ & 47 & $11 \%$ & 594 & $10 \%$ & 2752 & $9 \%$ & 2888 & $9 \%$ \\
\hline Trzo & nacicy & Tka & niękkie & & & Jel & grube & Trzc & nacicy \\
\hline 5125 & $7 \%$ & 29 & $7 \%$ & 367 & $6 \%$ & 2451 & $8 \%$ & 2216 & $7 \%$ \\
\hline & & & zyca & & hiak & & & & nik \\
\hline 3587 & $7 \%$ & 27 & $6 \%$ & 283 & $5 \%$ & 1893 & $6 \%$ & 1310 & $4 \%$ \\
\hline
\end{tabular}

Choroby nowotworowe u dzieci (0-19 lat) są stosunkowo rzadkie. W 2010 roku stanowiły $0,8 \%$ zachorowań na nowotwory ogółem wśród chłopców i 0,6\% wśród dziewcząt. Struktura zachorowań na nowotwory w tej grupie wiekowej zdecydowanie odbiega od obserwowanej w pozostałych grupach. Wśród zachorowań na nowotwory wieku dziecięcego najczęściej notowano w Polsce białaczki (31\% u chłopców, 26\% u dziewcząt), nowotwory mózgu i centralnego układu nerwowego (odpowiednio 17\% i 18\%), tkanek miękkich (odpowiednio 10\% i 7\%), jądra (9\%) i układu chłonnego (11\% i 7\%) (tab. V). Około 0,3\% zgonów nowotworowych występuje u chłopców, a 0,2\% u dziewcząt. Najczęściej są to nowotwory mózgu i centralnego układu nerwowego (odpowiednio 37\% i 35\%), białaczki (odpowiednio 27\% i 26\%) i nowotwory tkanek miękkich (odpowiednio 10\% i 12\%) (tab.V).

U młodych mężczyzn (20-44 lata) rozpoznaje się 5\% wszystkich nowotworów. Najczęstsze spośród nich to nowotwory jądra (25\%), jelita grubego (7\%) oraz mózgu i CUN (7\%).
U młodych kobiet występuje 8\% wszystkich zachorowań, wśród których najczęstsze to nowotwory piersi (27\%), rak szyjki macicy, włączając raki in situ (17\%) i nowotwory tarczycy (10\%) (tab. V). U młodych dorosłych występuje około 2-3\% zgonów nowotworowych. U mężczyzn najczęstszą przyczyną zgonu były nowotwory mózgu i CUN (12\%), rak płuca (12\%) i jelita grubego (8\%); u kobiet: rak piersi (21\%), szyjki macicy (12\%), nowotwory mózgu i CUN (9\%) oraz jajnika (9\%) (tab. VI).

Wśród mężczyzn 40\% nowotworów diagnozowanych jest w średnim wieku (45-64 lat). Najczęstsze z nich to rak płuca (24\%), jelita grubego (12\%) i gruczołu krokowego (9\%). W populacji kobiet w średnim wieku, w której występuje $44 \%$ wszystkich zachorowań, najczęstsze nowotwory to nowotwory piersi (28\%), płuca (10\%) i trzonu macicy (9\%) (tab.V). U osób w wieku 45-64 lat występuje ponad 1/3 zgonów nowotworowych. U mężczyzn dominuje rak płuca (35\%), jelita grubego (9\%) i żołądka (6\%), a u kobiet — rak płuca (21\%), piersi (16\%) i jajnika (8\%) (tab. VI). 
Tabela VI. Zgony na 5 najczęstszych nowotworów w Polsce w 2010 r. w zależności od płci i wieku

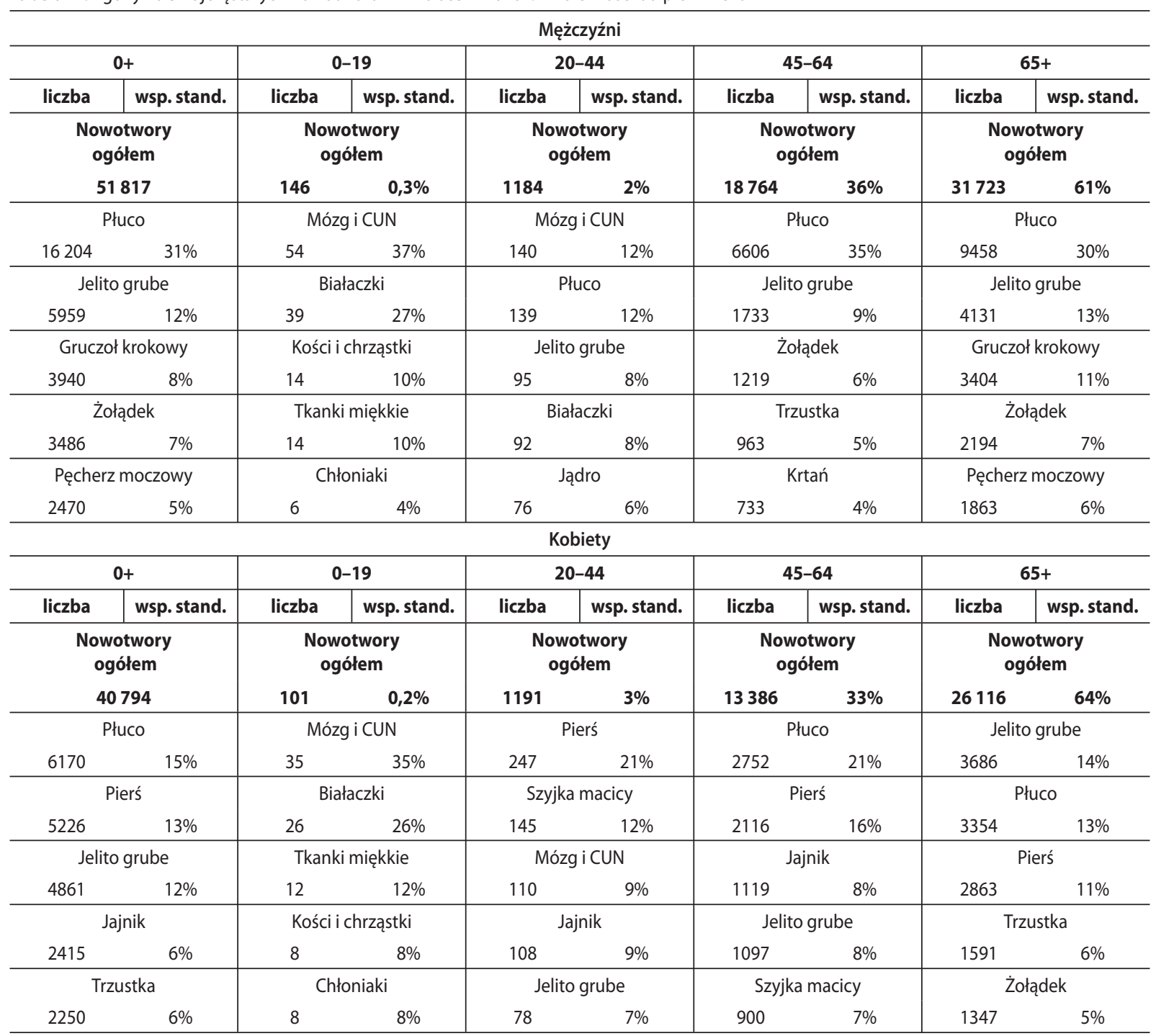

Wśród mężczyzn w najstarszej grupie wiekowej, u których rozpoznaje się 54\% wszystkich nowotworów, najczęściej występował rak płuca (21\%), gruczołu krokowego (18\%) i jelita grubego (14\%). W populacji kobiet po 65. roku życia, u których występuje $47 \%$ wszystkich zachorowań, najczęstsze nowotwory to rak piersi $(16 \%)$, jelita grubego (13\%) i płuca (9\%) (tab. V).

Ponad $60 \%$ wszystkich zgonów nowotworowych $(61 \%$ u mężczyzn i 64\% u kobiet) rejestrowanych jest u osób po 65 roku życia. Mężczyźni w tym wieku najczęściej umierają na raka płuca (30\%), jelita grubego (13\%) i gruczołu krokowego (11\%); kobiety — na raka jelita grubego (14\%), płuca (13\%) i piersi (11\%) (tab. VI).

\section{Średnioroczna zmiana trendów czasowych}

Dynamika zmian zachorowalności na nowotwory złośliwe w Polsce zmieniała się w czasie obserwacji (1980-2010). U mężczyzn zachorowalność rosła w tempie $0,5 \%$ rocznie do 1994 roku, po czym zaczęła spadać około 0,2\% rocznie. U kobiet w całym okresie obserwacji zachorowalność rosła w tempie $1,8 \%$ w dekadzie lat $80 . i$ 4,3\% w początku lat 90 . XX wieku, przy czym po 1993 r. tempo wzrostu zmniejszyło się do $1 \%$ rocznie (tab. VII). W większości lokalizacji włączonych do analizy obserwuje się rosnące trendy zachorowalności. Największy wzrost nastąpił w przypadku raka gruczołu krokowego w latach 1996-2010 (6,4\% rocznie), piersi (2,8\% rocznie w ciągu ostatnich 3 dekad) oraz płuca u kobiet (1,7\% rocznie po 1994 roku). Wyjątek stanowi rak płuca u mężczyzn, w przypadku którego po 1995 roku nastąpił dynamiczny spadek (2,6\% rocznie) (tab. VII, ryc. 6).

Nieco inaczej kształtują się trendy umieralności na poszczególne nowotwory w latach 1965-2010. Zarówno w populacji mężczyzn, jak i kobiet pod koniec lat 1980. nastąpiło zahamowanie wzrostu trendów umieralności, a na początku lat 2000 — ich spadek: u mężczyzn po 2004 roku 1,9\% rocznie, a u kobiet po 2006 roku 1,5\% rocznie (tab. VIII, ryc. 7). 
Tabela VII. Średnioroczna zmiana zachorowalności na najczęstsze nowotwory w Polsce w latach 1980-2010 (JoinPoint Regression)

\begin{tabular}{|c|c|c|c|c|c|c|}
\hline \multirow[t]{2}{*}{ Mężczyźni } & \multicolumn{2}{|c|}{ Trend 1} & \multicolumn{2}{|c|}{ Trend 2} & \multicolumn{2}{|c|}{ Trend 3} \\
\hline & Lata & Zmiana (\%) & Lata & Zmiana (\%) & Lata & Zmiana (\%) \\
\hline Ogółem & 1980-1994 & $+2,5^{*}$ & 1994-2010 & $-0,2^{*}$ & & \\
\hline Jelito grube & 1980-1990 & $+3,7^{*}$ & 1990-1995 & $+6,9 *$ & 1990-2010 & $+1,7^{*}$ \\
\hline Płuco & 1980-1986 & $+4,6^{*}$ & 1986-1995 & $+2,4^{*}$ & 1995-2010 & $-2,6^{*}$ \\
\hline Prostata & 1980-1996 & $+3,7^{*}$ & 1996-2010 & $+6,4^{*}$ & & \\
\hline \multirow[t]{2}{*}{ Kobiety } & \multicolumn{2}{|c|}{ Trend 1} & \multicolumn{2}{|c|}{ Trend 2} & \multicolumn{2}{|c|}{ Trend 3} \\
\hline & Lata & Zmiana (\%) & Lata & Zmiana (\%) & Lata & Zmiana (\%) \\
\hline Ogółem & 1980-1990 & $+1,8^{*}$ & 1990-1993 & $+4,3$ & 1993-2010 & $+1,0$ \\
\hline Jelito grube & 1980-1990 & $+2,7^{*}$ & 1990-1994 & $+6,3^{*}$ & 1994-2010 & $+0,8$ \\
\hline Płuco & 1980-1994 & $+5,8^{*}$ & 1994-2010 & $+1,7^{*}$ & & \\
\hline Pierś & 1980-2010 & $+2,8^{*}$ & & & & \\
\hline
\end{tabular}

*Zmiana istotna statystycznie

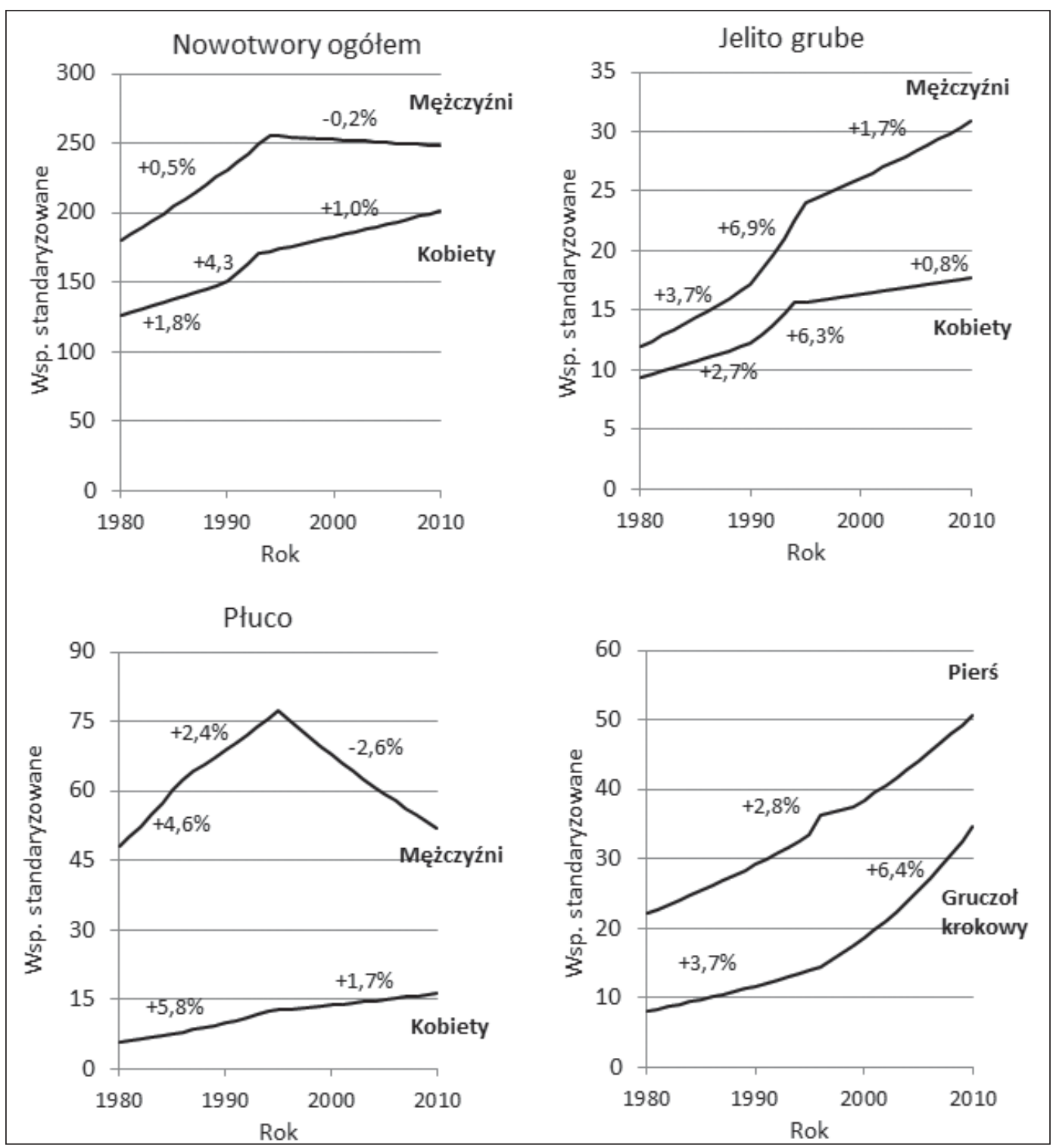

Rycina 6. Średnioroczna zmiana w zachorowalności na najczęstsze nowotwory w Polsce w latach 1965-2010 
W zależności od płci obserwuje się odmienne trendy umieralności na raka jelita grubego. U mężczyzn umieralność rośnie, jednak tempo wzrostu systematycznie zmniejsza się, aby po 1999 roku osiągnąć wartość 0,9\% rocznie. U kobiet zahamowanie wzrostu nastąpiło po 1996 roku, po czym nastąpił spadek umieralności (0,4\% rocznie) (tab. VIII, ryc. 7).

Odmienne trendy umieralności u mężczyzn i kobiet obserwuje się w raku płuca. U kobiet umieralność rośnie (po 1989 r. w tempie 2,6\% rocznie), a u mężczyzn od końca lat 1980. obserwuje się spadek, który od 2002 r. osiąga wartość 2,2\% rocznie (tab. VIII, ryc. 7). W trendach umieralności na nowotwory piersi u kobiet obserwuje się korzystne zmiany. Po okresie wzrostu od 1995 r. umieralność na nowotwory piersi zmniejsza się w tempie o 0,9\% rocznie. W latach 1965-2003 obserwuje się wzrost umieralności na raka prostaty, chociaż po 2004 roku nastąpił krótkotrwały spadek (o 0,4\% rocznie), jednak zmiana ta nie jest istotna statystycznie (tab. VIII, ryc. 7).

\section{Prawdopodobieństwo zachorowania i zgonu}

Skumulowane ryzyko zachorowania (zgonu) jest pewnym przybliżeniem życiowego ryzyka przy przyjęciu górnej granicy wieku bliskiej przeciętnemu trwaniu życia. W praktyce przyjęło się oznaczanie tej wartości dla wieku 0-74 lat. W Polsce w 2010 r. przeciętne trwanie życia mężczyzn wynosiło 72,1 lat i 80,6 lat dla kobiet.

Skumulowane ryzyko zachorowania na jakikolwiek nowotwór przed osiągnięciem 75 roku życia wynosiło 26,5\% wśród mężczyzn i 21,2\% wśród kobiet. W populacji mężczyzn skumulowane ryzyko zachorowania wynosiło: 6,7\% na raka płuca, 4,2\% na raka gruczołu krokowego i 3,7\% na raka jelita grubego. W populacji kobiet przed osiągnięciem 75. roku życia najwyższe skumulowane ryzyko zachorowania obserwowano dla raka piersi $(5,6 \%)$, raka jelita grubego $(2,2 \%)$ i raka płuca $(2,2 \%)$ (tab. IX).

Prawdopodobieństwo zachorowania z powodu jakiegokolwiek nowotworu w ciągu całego życia wynosiło w $2010 \mathrm{r}$. w Polsce około 30\% (30,0\% dla mężczyzn i 28,2\% dla kobiet). Życiowe ryzyko zachorowania mężczyzny w Polsce było najwyższe dla raka płuca (6,7\%), gruczołu krokowego (4,5\%) i jelita grubego (4\%) (tab. IX).

Skumulowane ryzyko zachorowania na nowotwór jest zależne od grupy wieku (ryc. 8). Wśród osób przed 20. rokiem życia ryzyko zachorowania jest bardzo niskie $(0,3 \%$ u mężczyzn i 0,2\% u kobiet). Ryzyko zgonu z powodu nowotworu w tym wieku wynosi około 0,05\% u obu płci. Wśród młodych dorosłych (między 20. a 44. rokiem życia) ryzyko zachorowania u mężczyzn wynosi 1,2\%, u kobiet - 2,2\%, natomiast ryzyko zgonu z powodu nowotworu nie przekracza 0,5\%. Wśród osób w średnim wieku (45-64 lat) ryzyko zachorowania wynosi około $11 \%$ u obu płci. W tej grupie wiekowej skumulowane ryzyko zgonu jest około 1,5 razy wyższe u mężczyzn niż u kobiet. W porównaniu z poprzed- nimi grupami wiekowymi w najstarszej grupie ryzyko zachorowania znacznie wzrasta, przy czym u mężczyzn jest prawie dwukrotnie wyższe niż u kobiet ( $25 \%$ vs 14,2\%). Podobnie skumulowane ryzyko zgonu jest najwyższe w najstarszej grupie wiekowej (20\% u mężczyzn i 10\% u kobiet) (ryc. 8).

\section{Regionalne zróżnicowanie w zachorowalności i umieralności na nowotwory w Polsce w 2010 roku}

Liczba zachorowań i zgonów na nowotwory złośliwe w województwach uzależniona jest głównie od wielkości populacji w województwie. W większości województw zachowana jest struktura zachorowań i zgonów typowa dla całej Polski (por. tab. X i XI). W populacji mężczyzn najwięcej zachorowań i zgonów w większości województw notuje się z powodu raka płuca, nowotworów jelita grubego i gruczołu krokowego. Wśród kobiet w większości województw, podobnie jak dla ogólnopolskiej populacji kobiet, najwięcej zgonów notuje się z powodu raka płuca. W województwie małopolskim i podkarpackim najwięcej zgonów wystąpiło w wyniku nowotworów piersi, a w województwie opolskim i podlaskim - w wyniku nowotworów jelita grubego.

Standaryzowane współczynniki zachorowalności na nowotwory złośliwe ogółem u mężczyzn dla poszczególnych województw mieszczą się w przedziale od 209/10 $0^{5}$ do 303/10 $0^{5}$ (tab. XII). Najwyższe wartości współczynniki te przyjmują w województwach: pomorskim, wielkopolskim i świętokrzyskim. Standaryzowane współczynniki zachorowalności na nowotwory złośliwe ogółem u kobiet wahają się od $176 / 10^{5}$ (województwo podlaskie) do $249 / 10^{5}$ (województwo pomorskie) (tab. XIII).

Standaryzowane współczynniki umieralności na nowotwory złośliwe ogółem u mężczyzn dla poszczególnych województw wahają się od 151/10 do 209/10 (tab. XII). Najwyższe wartości współczynniki te przyjmują w województwach: kujawsko-pomorskim, pomorskim i zachodniopomorskim. Standaryzowane współczynniki umieralności na nowotwory złośliwe ogółem u kobiet wahają się od $75 / 10^{5}$ (województwo podkarpackie) do $119 / 10^{5}$ (województwo kujawsko-pomorskie) (tab. XIII).

\section{Podsumowanie}

Prezentowany raport zawiera najnowsze dane na temat zachorowań i zgonów na nowotwory w 2010 roku oraz szacunki na rok 2012. W porównaniu do lat ubiegłych w 2010 roku nadal utrzymuje się dominująca pozycja raka płuca w populacji mężczyzn (zarówno w zachorowaniach, jak i w zgonach), chociaż jego częstość zmniejsza się. Nowotworami, których znaczenie rośnie u mężczyzn, są jelito grube i gruczoł krokowy. W populacji kobiet w całej Polsce obserwuje się rosnące zagrożenie rakiem płuca, czego przejawem jest jego dominująca pozycja w zgonach nowotworowych. Wśród zachorowań, podobnie jak w poprzednich latach, najczęstszy jest rak piersi i rak jelita grubego. Według 
Tabela VIII. Średnioroczna zmiana umieralności na najczęstsze nowotwory w Polsce w latach 1965-2010 (JoinPoint Regression)

\begin{tabular}{|c|c|c|c|c|c|c|c|c|}
\hline \multirow[t]{2}{*}{ Mężczyźni } & \multicolumn{2}{|c|}{ Trend 1} & \multicolumn{2}{|c|}{ Trend 2} & \multicolumn{2}{|c|}{ Trend 3} & \multicolumn{2}{|c|}{ Trend 4} \\
\hline & Lata & Zmiana (\%) & Lata & Zmiana (\%) & Lata & Zmiana (\%) & Lata & Zmiana (\%) \\
\hline Ogółem & 1965-1978 & $+1,4^{*}$ & 1978-1988 & $+1,8^{*}$ & 1988-2004 & $-0,04^{*}$ & 2004-2010 & $-1,9^{*}$ \\
\hline Jelito grube & 1965-1974 & $+4,4^{*}$ & 1974-1999 & $+2,4^{*}$ & 1999-2010 & $+0,9$ & & \\
\hline Płuco & 1965-1973 & $+5,3^{*}$ & 1973-1988 & $+3,5^{*}$ & 1988-2002 & $-0,3^{*}$ & $2002-2010$ & $-2,2^{*}$ \\
\hline Prostata & 1965-1982 & $+0,4^{*}$ & 1982-2003 & $+2,1^{*}$ & 2003-2010 & $-0,4$ & & \\
\hline \multirow[t]{2}{*}{ Kobiety } & \multicolumn{2}{|c|}{ Trend 1} & \multicolumn{2}{|c|}{ Trend 2} & \multicolumn{2}{|c|}{ Trend 3} & \multicolumn{2}{|c|}{ Trend 3} \\
\hline & Lata & Zmiana (\%) & Lata & Zmiana (\%) & Lata & Zmiana (\%) & Lata & Zmiana (\%) \\
\hline Ogółem & 1965-1976 & $-0,4^{*}$ & 1976-1987 & $+0,6^{*}$ & 1987-2006 & $-0,1^{*}$ & $2006-2010$ & $-1,5^{*}$ \\
\hline Jelito grube & 1965-1983 & $+2,6^{*}$ & 1983-1996 & $+1,1$ & 1996-2010 & $-0,4^{*}$ & & \\
\hline Płuco & 1965-1973 & $+1,9^{*}$ & 1973-1989 & $+3,7^{*}$ & 1989-2010 & $+2,6^{*}$ & & \\
\hline Pierś & 1965-1981 & $+2,1^{*}$ & 1981-1995 & $+0,5^{*}$ & $1995-2010$ & $-0,9^{*}$ & & \\
\hline
\end{tabular}

*Zmiana istotna statystycznie

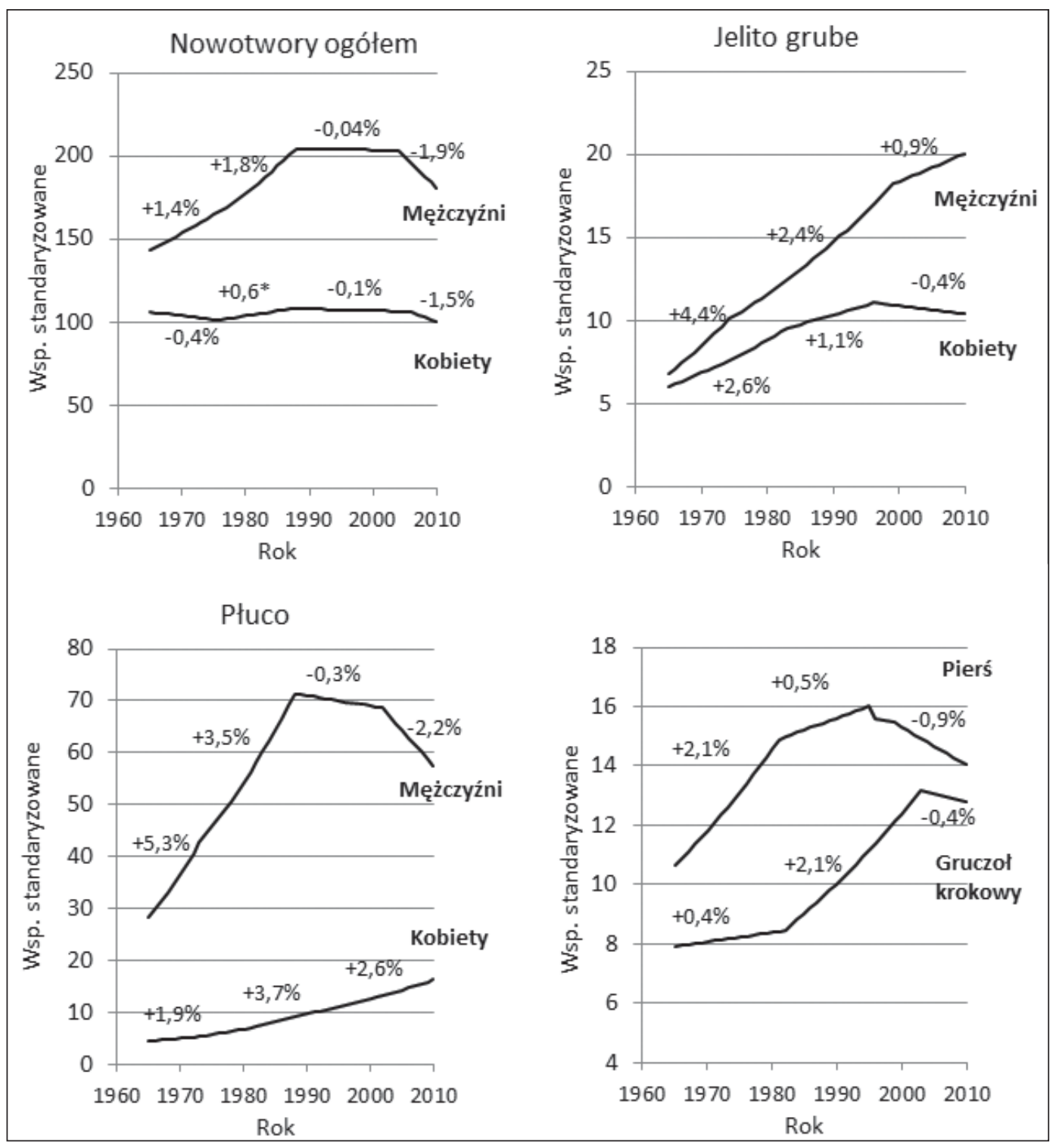

Rycina 7. Średnioroczna zmiana w umieralności na najczęstsze nowotwory w Polsce w latach 1965-2010 
Tabela IX. Prawdopodobieństwo zachorowania (w \%) na najczęstsze nowotwory w Polsce w 2010 r. według płci

\begin{tabular}{|c|c|c|c|c|c|}
\hline \multirow[t]{2}{*}{ Nowotwór } & \multirow[t]{2}{*}{ ICD-10 } & \multicolumn{2}{|c|}{ Skumulowane ryzyko zachorowania 0-74 } & \multicolumn{2}{|c|}{ Życiowe ryzyko zachorowania } \\
\hline & & Mężczyźni & Kobiety & Mężczyźni & Kobiety \\
\hline Ogółem & $\mathrm{C} 00-\mathrm{C} 96$ & 26,5 & 21,2 & 30,0 & 28,2 \\
\hline Żołądek & C16 & 1,5 & 0,5 & 1,6 & 0,9 \\
\hline Jelito grube & $\mathrm{C} 81-\mathrm{C} 21$ & 3,7 & 2,2 & 4,0 & 3,3 \\
\hline Płuco & C33-C34 & 6,7 & 2,2 & 6,7 & 2,6 \\
\hline Czerniak skóry & $\mathrm{C} 43$ & 0,5 & 0,5 & 0,5 & 0,6 \\
\hline Pierś & C50 & & 5,6 & & 6,3 \\
\hline Szyjka macicy & C53 & & 1,1 & & 1,2 \\
\hline Trzon macicy & C54 & & 1,9 & & 2,1 \\
\hline Jajnik & C56 & & 1,3 & & 1,5 \\
\hline Gruczoł krokowy & C61 & 4,2 & & 4,5 & \\
\hline Jądro & C62 & 0,4 & & 0,4 & \\
\hline Nerka & C64 & 1,3 & 0,7 & 1,2 & 0,8 \\
\hline Pęcherz moczowy & $\mathrm{C} 67$ & 2,1 & 0,4 & 2,3 & 0,6 \\
\hline Mózg & C71 & 0,6 & 0,5 & 0,6 & 0,6 \\
\hline Chłoniaki Hodgkina & $\mathrm{C} 81$ & 0,1 & 0,1 & 0,1 & 0,1 \\
\hline Chłoniaki nieziarnicze & $\mathrm{C} 82-\mathrm{C} 85+\mathrm{C} 96$ & 0,6 & 0,4 & 0,6 & 0,6 \\
\hline Białaczki & C91-C95 & 0,7 & 0,4 & 0,7 & 0,6 \\
\hline
\end{tabular}

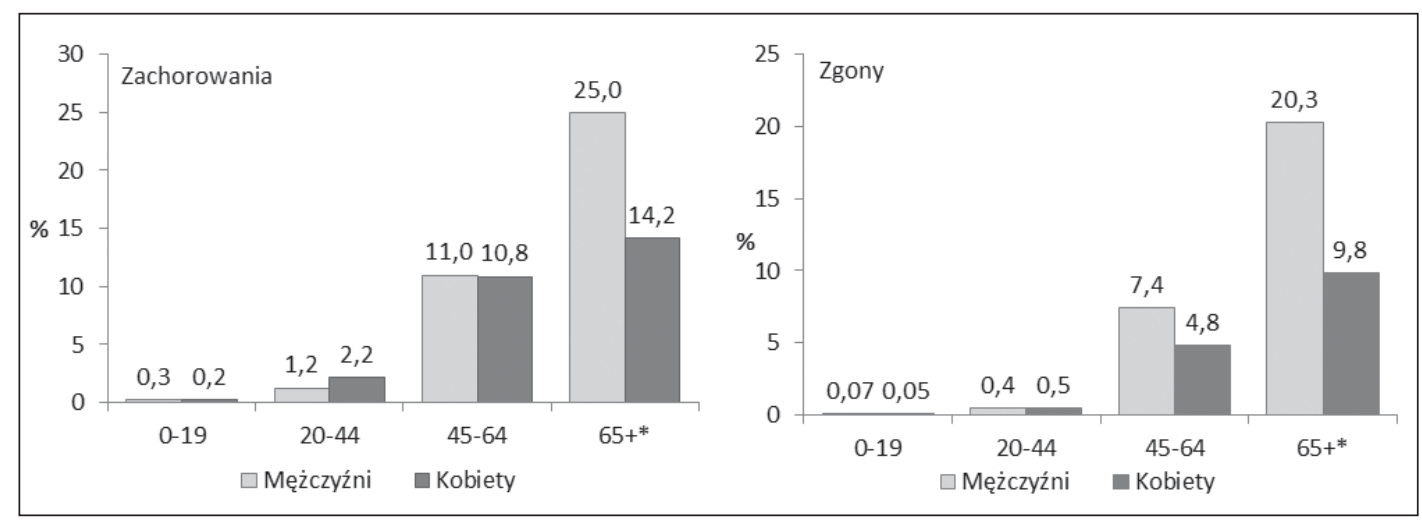

Rycina 8. Skumulowane ryzyko zachorowania i zgonu na nowotwór w Polsce w 2010 r. według płci i wieku

Tabela X. Liczby zachorowań i zgonów na najczęstsze nowotwory złośliwe u mężczyzn w Polsce w 2010 r. według województw

\begin{tabular}{|c|c|c|c|c|c|c|c|c|c|}
\hline \multirow[t]{2}{*}{ Województwo } & Ogółem & Żołądek & $\begin{array}{l}\text { Jelito } \\
\text { grube }^{1}\end{array}$ & Płuco & $\begin{array}{l}\text { Gruczoł } \\
\text { krokowy }\end{array}$ & Nerka & $\begin{array}{l}\text { Pęcherz } \\
\text { moczowy }\end{array}$ & Białaczki $^{2}$ & Chłoniaki $^{3}$ \\
\hline & \multicolumn{9}{|c|}{ Liczba zachorowań } \\
\hline Dolnośląskie & 5740 & 268 & 722 & 1214 & 608 & 232 & 411 & 99 & 144 \\
\hline Kujawsko-pomorskie & 3945 & 183 & 491 & 887 & 523 & 148 & 325 & 105 & 67 \\
\hline Lubelskie & 4122 & 153 & 475 & 907 & 572 & 154 & 351 & 87 & 132 \\
\hline Lubuskie & 1732 & 95 & 234 & 339 & 291 & 63 & 73 & 25 & 39 \\
\hline Łódzkie & 4828 & 270 & 627 & 1095 & 455 & 165 & 346 & 93 & 135 \\
\hline Małopolskie & 5493 & 311 & 669 & 1171 & 785 & 203 & 415 & 107 & 78 \\
\hline Mazowieckie & 8420 & 346 & 1047 & 1819 & 1339 & 319 & 521 & 170 & 104 \\
\hline Opolskie & 1936 & 113 & 265 & 360 & 194 & 76 & 153 & 25 & 55 \\
\hline Podkarpackie & 3904 & 214 & 466 & 696 & 528 & 215 & 304 & 111 & 154 \\
\hline Podlaskie & 1836 & 94 & 243 & 354 & 299 & 81 & 138 & 23 & 31 \\
\hline Pomorskie & 4790 & 227 & 529 & 946 & 746 & 195 & 397 & 98 & 93 \\
\hline Śląskie & 8563 & 412 & 1025 & 1790 & 1218 & 328 & 525 & 186 & 218 \\
\hline
\end{tabular}


Tabela X. Liczby zachorowań i zgonów na najczęstsze nowotwory złośliwe u mężczyzn w Polsce w 2010 r. według województw (cd.)

\begin{tabular}{|c|c|c|c|c|c|c|c|c|c|}
\hline \multirow[t]{2}{*}{ Województwo } & Ogółem & Żołądek & $\begin{array}{l}\text { Jelito } \\
\text { grube }^{1}\end{array}$ & Płuco & $\begin{array}{l}\text { Gruczoł } \\
\text { krokowy }\end{array}$ & Nerka & $\begin{array}{l}\text { Pęcherz } \\
\text { moczowy }\end{array}$ & Białaczki $^{2}$ & Chłoniaki $^{3}$ \\
\hline & \multicolumn{9}{|c|}{ Liczba zachorowań } \\
\hline Świętokrzyskie & 2760 & 139 & 359 & 579 & 305 & 108 & 211 & 65 & 64 \\
\hline Warmińsko-mazurskie & 2513 & 144 & 313 & 706 & 231 & 103 & 155 & 39 & 54 \\
\hline Wielkopolskie & 6722 & 327 & 876 & 1256 & 843 & 265 & 419 & 159 & 168 \\
\hline $\begin{array}{l}\text { Zachodnio- } \\
\text { pomorskie }\end{array}$ & 2720 & 103 & 344 & 700 & 336 & 81 & 175 & 60 & 37 \\
\hline \multirow[t]{2}{*}{ Polska } & 70024 & 3399 & 8685 & 14819 & 9273 & 2736 & 4919 & 1452 & 1573 \\
\hline & \multicolumn{9}{|c|}{ Liczba zgonów } \\
\hline Dolnośląskie & 4084 & 263 & 466 & 1276 & 279 & 112 & 195 & 39 & 120 \\
\hline Kujawsko-pomorskie & 3140 & 215 & 346 & 1053 & 227 & 86 & 132 & 57 & 76 \\
\hline Lubelskie & 2704 & 143 & 295 & 874 & 232 & 91 & 101 & 43 & 93 \\
\hline Lubuskie & 1271 & 97 & 137 & 384 & 84 & 36 & 59 & 20 & 33 \\
\hline Łódzkie & 3763 & 277 & 414 & 1178 & 301 & 98 & 187 & 52 & 97 \\
\hline Małopolskie & 4120 & 287 & 500 & 1208 & 336 & 141 & 216 & 64 & 109 \\
\hline Mazowieckie & 7009 & 431 & 791 & 2326 & 514 & 192 & 337 & 115 & 183 \\
\hline Opolskie & 1326 & 93 & 171 & 381 & 110 & 37 & 93 & 14 & 32 \\
\hline Podkarpackie & 2326 & 171 & 227 & 690 & 203 & 78 & 103 & 55 & 74 \\
\hline Podlaskie & 1628 & 106 & 200 & 499 & 165 & 65 & 77 & 20 & 49 \\
\hline Pomorskie & 3137 & 199 & 333 & 997 & 223 & 102 & 156 & 38 & 82 \\
\hline Śląskie & 6599 & 511 & 832 & 1918 & 472 & 218 & 289 & 94 & 187 \\
\hline Świętokrzyskie & 1771 & 114 & 212 & 597 & 153 & 41 & 76 & 30 & 40 \\
\hline Warmińsko-mazurskie & 1917 & 143 & 192 & 715 & 123 & 62 & 102 & 34 & 60 \\
\hline Wielkopolskie & 4603 & 292 & 568 & 1356 & 352 & 141 & 222 & 77 & 141 \\
\hline Zachodniopomorskie & 2419 & 144 & 275 & 752 & 166 & 74 & 125 & 43 & 55 \\
\hline Polska & 51817 & 3486 & 5959 & 16204 & 3940 & 1574 & 2470 & 795 & 1431 \\
\hline
\end{tabular}

1Jelito grube C18-C21; ${ }^{2}$ Chłoniaki C82-C85+C96; ${ }^{3}$ Białaczki C91-C95

Tabela XI. Liczby zachorowań i zgonów na najczęstsze nowotwory złośliwe u kobiet w Polsce w 2010 r. według województw

\begin{tabular}{|c|c|c|c|c|c|c|c|c|c|c|}
\hline \multirow[t]{2}{*}{ Województwo } & Ogółem & $\begin{array}{l}\text { Jelito } \\
\text { grube }^{1}\end{array}$ & Płuco & Pierś & $\begin{array}{l}\text { Szyjka } \\
\text { macicy }\end{array}$ & Jajnik & Nerka & $\begin{array}{l}\text { Pęcherz } \\
\text { moczowy }\end{array}$ & Chłoniaki $^{3}$ & Białaczki $^{2}$ \\
\hline & \multicolumn{10}{|c|}{ Liczba zachorowań } \\
\hline Dolnośląskie & 5964 & 618 & 544 & 1335 & 255 & 285 & 133 & 117 & 125 & 109 \\
\hline Kujawsko-pomorskie & 4169 & 390 & 409 & 864 & 223 & 250 & 122 & 101 & 90 & 55 \\
\hline Lubelskie & 3885 & 366 & 268 & 848 & 136 & 222 & 136 & 83 & 90 & 101 \\
\hline Lubuskie & 1803 & 205 & 167 & 428 & 93 & 91 & 57 & 26 & 25 & 43 \\
\hline Łódzkie & 5371 & 530 & 475 & 1253 & 200 & 288 & 119 & 114 & 87 & 129 \\
\hline Małopolskie & 5527 & 579 & 356 & 1235 & 247 & 308 & 164 & 133 & 104 & 81 \\
\hline Mazowieckie & 8797 & 850 & 845 & 2102 & 408 & 400 & 205 & 143 & 156 & 97 \\
\hline Opolskie & 1797 & 200 & 127 & 376 & 70 & 112 & 48 & 27 & 35 & 41 \\
\hline Podkarpackie & 3461 & 364 & 195 & 654 & 126 & 182 & 138 & 63 & 89 & 142 \\
\hline Podlaskie & 1784 & 203 & 121 & 410 & 105 & 100 & 54 & 28 & 28 & 16 \\
\hline Pomorskie & 4787 & 492 & 428 & 1063 & 226 & 228 & 129 & 128 & 100 & 92 \\
\hline Śląskie & 8352 & 845 & 773 & 1834 & 368 & 426 & 234 & 143 & 164 & 181 \\
\hline Świętokrzyskie & 2493 & 250 & 167 & 426 & 102 & 126 & 56 & 59 & 37 & 63 \\
\hline Warmińsko-mazurskie & 2574 & 255 & 286 & 580 & 155 & 132 & 76 & 62 & 45 & 37 \\
\hline Wielkopolskie & 6859 & 697 & 533 & 1586 & 223 & 303 & 185 & 103 & 152 & 139 \\
\hline Zachodniopomorskie & 2917 & 271 & 358 & 790 & 141 & 134 & 52 & 47 & 40 & 31 \\
\hline Polska & 70540 & 7115 & 6052 & 15784 & 3078 & 3587 & 1908 & 1377 & 1367 & 1357 \\
\hline
\end{tabular}


Tabela XI. Liczby zachorowań i zgonów na najczęstsze nowotwory złośliwe u kobiet w Polsce w 2010 r. według województw (cd.)

\begin{tabular}{|c|c|c|c|c|c|c|c|c|c|c|}
\hline \multirow[t]{2}{*}{ Województwo } & Ogółem & $\begin{array}{l}\text { Jelito } \\
\text { grube }{ }^{1}\end{array}$ & Płuco & Pierś & $\begin{array}{l}\text { Szyjka } \\
\text { macicy }\end{array}$ & Jajnik & Nerka & $\begin{array}{l}\text { Pęcherz } \\
\text { moczowy }\end{array}$ & Chłoniaki $^{3}$ & Białaczki ${ }^{2}$ \\
\hline & \multicolumn{10}{|c|}{ Liczba zgonów } \\
\hline Dolnośląskie & 3275 & 406 & 555 & 370 & 126 & 180 & 64 & 54 & 45 & 94 \\
\hline Kujawsko-pomorskie & 2597 & 301 & 445 & 303 & 100 & 155 & 67 & 40 & 40 & 66 \\
\hline Lubelskie & 1931 & 229 & 250 & 249 & 77 & 115 & 40 & 26 & 49 & 54 \\
\hline Lubuskie & 1088 & 127 & 196 & 142 & 61 & 50 & 19 & 17 & 11 & 42 \\
\hline Łódzkie & 3080 & 339 & 461 & 410 & 126 & 194 & 64 & 46 & 33 & 85 \\
\hline Małopolskie & 3274 & 402 & 394 & 446 & 123 & 206 & 94 & 50 & 60 & 81 \\
\hline Mazowieckie & 5950 & 648 & 1034 & 794 & 244 & 368 & 121 & 98 & 96 & 168 \\
\hline Opolskie & 1006 & 154 & 135 & 125 & 53 & 77 & 30 & 13 & 13 & 33 \\
\hline Podkarpackie & 1607 & 177 & 168 & 219 & 70 & 92 & 48 & 22 & 38 & 70 \\
\hline Podlaskie & 1146 & 155 & 135 & 130 & 62 & 93 & 26 & 18 & 20 & 37 \\
\hline Pomorskie & 2416 & 284 & 396 & 316 & 99 & 145 & 57 & 39 & 44 & 63 \\
\hline Śląskie & 5153 & 616 & 757 & 711 & 254 & 349 & 144 & 87 & 99 & 169 \\
\hline Świętokrzyskie & 1237 & 151 & 147 & 173 & 45 & 74 & 28 & 18 & 22 & 43 \\
\hline Warmińsko-mazurskie & 1533 & 209 & 277 & 176 & 79 & 80 & 41 & 36 & 34 & 31 \\
\hline Wielkopolskie & 3615 & 451 & 481 & 466 & 127 & 231 & 81 & 41 & 68 & 122 \\
\hline Zachodniopomorskie & 1886 & 212 & 339 & 196 & 89 & 138 & 30 & 36 & 30 & 53 \\
\hline Polska & 40794 & 4861 & 6170 & 5226 & 1735 & 2547 & 954 & 641 & 702 & 1211 \\
\hline
\end{tabular}

${ }^{1}$ Jelito grube C18-C21; ${ }^{2}$ Chłoniaki C82-C85+C96; ${ }^{3}$ Białaczki C91-C95

Tabela XII. Standaryzowane współczynniki zachorowalności i umieralności na najczęstsze nowotwory złośliwe u mężczyzn w Polsce w 2010 r. według województw

\begin{tabular}{|c|c|c|c|c|c|c|c|c|c|}
\hline \multirow[t]{2}{*}{ Województwo } & Ogółem & Żołądek & $\begin{array}{l}\text { Jelito } \\
\text { grube }^{1}\end{array}$ & Płuco & $\begin{array}{l}\text { Gruczoł } \\
\text { krokowy }\end{array}$ & Nerka & $\begin{array}{l}\text { Pęcherz } \\
\text { moczowy }\end{array}$ & Białaczki $^{2}$ & Chłoniaki $^{3}$ \\
\hline & \multicolumn{9}{|c|}{ Zachorowalność } \\
\hline Dolnośląskie & 267,0 & 12,4 & 33,1 & 55,4 & 27,9 & 10,8 & 18,6 & 4,8 & 7,9 \\
\hline Kujawsko-pomorskie & 270,6 & 12,3 & 33,0 & 59,1 & 35,8 & 10,1 & 22,2 & 7,7 & 5,7 \\
\hline Lubelskie & 255,5 & 9,3 & 28,9 & 55,8 & 33,1 & 9,9 & 20,6 & 5,6 & 10,0 \\
\hline Lubuskie & 248,7 & 13,3 & 33,0 & 48,3 & 41,4 & 8,6 & 10,4 & 3,7 & 7,8 \\
\hline Łódzkie & 248,9 & 13,8 & 31,6 & 55,5 & 23,1 & 8,7 & 16,9 & 4,7 & 7,3 \\
\hline Małopolskie & 233,1 & 12,7 & 27,3 & 48,3 & 31,8 & 9,0 & 17,0 & 4,8 & 4,7 \\
\hline Mazowieckie & 215,9 & 8,6 & 25,8 & 46,4 & 33,2 & 8,4 & 12,6 & 4,4 & 3,6 \\
\hline Opolskie & 254,5 & 14,2 & 33,4 & 46,9 & 24,7 & 10,4 & 19,6 & 3,2 & 8,0 \\
\hline Podkarpackie & 264,0 & 14,3 & 30,8 & 46,8 & 34,5 & 15,0 & 19,4 & 8,4 & 11,0 \\
\hline Podlaskie & 208,6 & 10,7 & 26,8 & 40,1 & 33,0 & 9,3 & 14,4 & 2,8 & 5,4 \\
\hline Pomorskie & 302,5 & 13,9 & 32,1 & 58,5 & 45,9 & 12,8 & 24,5 & 6,9 & 7,2 \\
\hline Śląskie & 241,5 & 11,3 & 28,1 & 49,5 & 33,2 & 9,4 & 14,2 & 5,5 & 7,2 \\
\hline Świętokrzyskie & 274,1 & 13,3 & 34,0 & 56,1 & 27,9 & 11,4 & 20,1 & 7,3 & 7,7 \\
\hline Warmińsko-mazurskie & 259,2 & 14,4 & 32,5 & 71,3 & 23,5 & 10,7 & 16,2 & 3,7 & 5,9 \\
\hline Wielkopolskie & 287,2 & 13,6 & 36,8 & 53,2 & 35,8 & 11,5 & 17,4 & 7,4 & 8,2 \\
\hline Zachodniopomorskie & 223,4 & 8,0 & 27,1 & 55,9 & 28,0 & 6,8 & 13,6 & 5,5 & 4,3 \\
\hline Polska & 251,0 & 11,9 & 30,2 & 52,3 & 32,3 & 10,0 & 17,0 & 5,5 & 6,8 \\
\hline \multicolumn{10}{|c|}{ Umieralność } \\
\hline Dolnośląskie & 185,4 & 11,9 & 20,7 & 58,1 & 11,8 & 5,1 & 8,8 & 1,8 & 5,8 \\
\hline Kujawsko-pomorskie & 208,6 & 14,1 & 23,2 & 69,8 & 14,1 & 5,7 & 8,8 & 3,9 & 5,3 \\
\hline Lubelskie & 161,3 & 8,4 & 17,0 & 52,9 & 11,9 & 5,4 & 5,6 & 2,6 & 6,1 \\
\hline
\end{tabular}


Tabela XII. Standaryzowane współczynniki zachorowalności i umieralności na najczęstsze nowotwory złośliwe u mężczyzn w Polsce w 2010 r. według województw (cd.)

\begin{tabular}{|c|c|c|c|c|c|c|c|c|c|}
\hline \multirow[t]{2}{*}{ Województwo } & Ogółem & Żołądek & $\begin{array}{c}\text { Jelito } \\
\text { grube }^{1}\end{array}$ & Płuco & $\begin{array}{l}\text { Gruczoł } \\
\text { krokowy }\end{array}$ & Nerka & $\begin{array}{l}\text { Pęcherz } \\
\text { moczowy }\end{array}$ & Białaczki $^{2}$ & Chłoniaki $^{3}$ \\
\hline & \multicolumn{9}{|c|}{ Umieralność } \\
\hline Lubuskie & 175,7 & 13,3 & 18,8 & 53,2 & 11,1 & 5,1 & 7,7 & 2,7 & 4,8 \\
\hline Łódzkie & 184,4 & 13,8 & 19,9 & 58,6 & 13,3 & 5,1 & 8,7 & 2,8 & 4,9 \\
\hline Małopolskie & 165,1 & 11,5 & 19,4 & 48,5 & 12,2 & 5,9 & 8,5 & 2,5 & 4,4 \\
\hline Mazowieckie & 169,8 & 10,1 & 18,3 & 58,1 & 10,9 & 4,7 & 7,5 & 2,8 & 4,7 \\
\hline Opolskie & 168,3 & 12,0 & 21,4 & 47,8 & 12,3 & 4,5 & 11,9 & 1,6 & 4,4 \\
\hline Podkarpackie & 150,9 & 11,1 & 14,4 & 45,3 & 11,6 & 5,2 & 6,3 & 3,5 & 4,8 \\
\hline Podlaskie & 168,9 & 11,0 & 19,0 & 53,6 & 15,6 & 6,5 & 6,9 & 2,1 & 5,0 \\
\hline Pomorskie & 191,8 & 11,9 & 20,0 & 61,1 & 12,9 & 6,2 & 9,2 & 2,4 & 5,1 \\
\hline Śląskie & 180,1 & 13,6 & 22,3 & 52,0 & 12,3 & 5,9 & 7,4 & 2,7 & 5,3 \\
\hline Świętokrzyskie & 169,5 & 11,1 & 20,0 & 58,2 & 12,5 & 4,2 & 7,0 & 2,7 & 3,9 \\
\hline Warmińsko-mazurskie & 190,8 & 13,8 & 19,1 & 71,4 & 11,4 & 6,4 & 9,9 & 3,1 & 6,3 \\
\hline Wielkopolskie & 191,6 & 12,1 & 23,0 & 56,9 & 13,9 & 5,7 & 9,0 & 3,2 & 6,2 \\
\hline Zachodniopomorskie & 191,8 & 11,0 & 21,4 & 59,5 & 12,3 & 5,9 & 9,7 & 3,4 & 5,0 \\
\hline Polska & 178,3 & 11,8 & 20,0 & 56,2 & 12,4 & 5,4 & 8,1 & 2,8 & 5,1 \\
\hline
\end{tabular}

1Jelito grube C18-C21; ${ }^{2}$ Chłoniaki C82-C85+C96; ${ }^{3}$ Białaczki C91-C95

Tabela XIII. Standaryzowane współczynniki zachorowalności i umieralności na najczęstsze nowotwory złośliwe u kobiet w Polsce w 2010 r. według województw

\begin{tabular}{|c|c|c|c|c|c|c|c|c|c|c|}
\hline \multirow[t]{2}{*}{ Województwo } & Ogółem & $\begin{array}{c}\text { Jelito } \\
\text { grube }^{1}\end{array}$ & Płuco & Pierś & $\begin{array}{l}\text { Szyjka } \\
\text { macicy }\end{array}$ & Jajnik & Nerka & $\begin{array}{l}\text { Pęcherz } \\
\text { moczowy }\end{array}$ & Chłoniaki ${ }^{3}$ & Białaczki $^{2}$ \\
\hline & \multicolumn{10}{|c|}{ Zachorowalność } \\
\hline Dolnośląskie & 214,7 & 19,6 & 18,1 & 52,7 & 11,0 & 10,9 & 4,8 & 3,6 & 4,5 & 4,5 \\
\hline Kujawsko-pomorskie & 232,9 & 18,3 & 22,4 & 51,3 & 13,4 & 15,1 & 6,9 & 5,0 & 5,2 & 3,7 \\
\hline Lubelskie & 198,8 & 16,0 & 13,7 & 47,8 & 8,1 & 12,7 & 7,0 & 3,7 & 4,5 & 6,1 \\
\hline Lubuskie & 204,9 & 20,3 & 19,0 & 51,1 & 12,2 & 11,4 & 6,7 & 2,6 & 2,9 & 5,0 \\
\hline Łódzkie & 214,8 & 18,2 & 19,0 & 55,8 & 9,3 & 13,0 & 4,4 & 3,9 & 3,9 & 4,9 \\
\hline Małopolskie & 192,9 & 18,1 & 11,9 & 46,6 & 9,8 & 11,5 & 6,0 & 4,0 & 3,6 & 2,8 \\
\hline Mazowieckie & 182,4 & 15,1 & 16,3 & 47,3 & 10,1 & 8,9 & 4,2 & 2,4 & 3,0 & 2,9 \\
\hline Opolskie & 187,8 & 18,1 & 13,7 & 42,0 & 8,5 & 13,5 & 4,6 & 2,6 & 3,3 & 4,8 \\
\hline Podkarpackie & 190,7 & 18,0 & 10,2 & 39,4 & 8,0 & 10,8 & 7,3 & 3,4 & 5,0 & 7,8 \\
\hline Podlaskie & 175,9 & 17,3 & 11,5 & 42,4 & 11,2 & 10,8 & 5,1 & 2,1 & 2,8 & 2,7 \\
\hline Pomorskie & 249,3 & 22,9 & 22,0 & 59,1 & 13,3 & 12,8 & 6,3 & 6,1 & 4,9 & 5,7 \\
\hline Śląskie & 194,8 & 18,1 & 17,3 & 45,5 & 9,6 & 10,7 & 5,4 & 2,9 & 3,7 & 4,6 \\
\hline Świętokrzyskie & 203,2 & 16,9 & 12,4 & 39,4 & 10,1 & 10,9 & 3,9 & 4,5 & 3,0 & 5,0 \\
\hline Warmińsko-mazurskie & 215,1 & 18,7 & 22,9 & 52,0 & 14,5 & 11,8 & 5,8 & 4,5 & 3,7 & 3,7 \\
\hline Wielkopolskie & 235,3 & 20,6 & 18,0 & 58,6 & 8,9 & 10,9 & 6,0 & 3,1 & 5,4 & 5,6 \\
\hline Zachodniopomorskie & 193,4 & 16,0 & 22,4 & 54,7 & 10,4 & 9,8 & 3,1 & 2,6 & 2,6 & 2,3 \\
\hline \multirow[t]{2}{*}{ Polska } & 205,0 & 18,1 & 16,9 & 49,6 & 10,3 & 11,3 & 5,4 & 3,5 & 3,9 & 4,4 \\
\hline & \multicolumn{10}{|c|}{ Umieralność } \\
\hline Dolnośląskie & 99,1 & 11,0 & 17,7 & 12,3 & 5,1 & 6,0 & 1,7 & 1,3 & 1,4 & 2,6 \\
\hline Kujawsko-pomorskie & 119,4 & 12,1 & 22,5 & 14,8 & 5,3 & 8,2 & 2,8 & 1,5 & 1,9 & 3,1 \\
\hline Lubelskie & 83,5 & 8,8 & 12,3 & 11,9 & 4,0 & 5,7 & 1,5 & 1,0 & 1,9 & 2,3 \\
\hline Lubuskie & 106,2 & 11,0 & 20,2 & 14,2 & 7,5 & 5,0 & 1,9 & 1,5 & 0,9 & 4,1 \\
\hline Łódzkie & 103,3 & 9,9 & 17,1 & 15,3 & 5,0 & 7,1 & 1,9 & 1,3 & 1,2 & 2,7 \\
\hline Małopolskie & 92,2 & 10,0 & 12,1 & 13,6 & 4,3 & 6,6 & 2,3 & 1,3 & 1,8 & 2,1 \\
\hline
\end{tabular}


Tabela XIII. Standaryzowane współczynniki zachorowalności i umieralności na najczęstsze nowotwory złośliwe u kobiet w Polsce w 2010 r. według województw (cd.)

\begin{tabular}{|c|c|c|c|c|c|c|c|c|c|c|}
\hline \multirow[t]{2}{*}{ Województwo } & Ogółem & $\begin{array}{c}\text { Jelito } \\
\text { grube }^{1}\end{array}$ & Płuco & Pierś & $\begin{array}{l}\text { Szyjka } \\
\text { macicy }\end{array}$ & Jajnik & Nerka & $\begin{array}{l}\text { Pęcherz } \\
\text { moczowy }\end{array}$ & Chłoniaki $^{3}$ & Białaczki $^{2}$ \\
\hline & \multicolumn{10}{|c|}{ Umieralność } \\
\hline Mazowieckie & 100,3 & 9,1 & 18,9 & 14,6 & 5,4 & 7,0 & 1,8 & 1,2 & 1,6 & 2,9 \\
\hline Opolskie & 90,9 & 12,0 & 13,9 & 12,1 & 5,7 & 8,1 & 2,3 & 0,9 & 1,0 & 3,2 \\
\hline Podkarpackie & 74,9 & 7,3 & 8,8 & 11,5 & 3,6 & 4,6 & 2,4 & 0,8 & 1,7 & 2,9 \\
\hline Podlaskie & 88,0 & 10,9 & 11,3 & 11,3 & 5,7 & 8,7 & 1,8 & 1,0 & 1,7 & 3,3 \\
\hline Pomorskie & 106,3 & 11,0 & 18,5 & 14,5 & 5,3 & 7,5 & 2,3 & 1,4 & 2,0 & 3,1 \\
\hline Śląskie & 104,3 & 10,9 & 16,4 & 15,3 & 6,0 & 7,6 & 2,8 & 1,5 & 2,0 & 3,4 \\
\hline Świętokrzyskie & 87,4 & 9,9 & 11,2 & 13,6 & 3,9 & 6,2 & 1,5 & 1,0 & 1,8 & 3,0 \\
\hline Warmińsko-mazurskie & 109,3 & 13,3 & 21,7 & 13,0 & 6,5 & 6,4 & 2,8 & 2,0 & 2,6 & 2,2 \\
\hline Wielkopolskie & 105,6 & 11,8 & 15,3 & 13,9 & 4,6 & 7,6 & 2,3 & 1,1 & 2,2 & 3,5 \\
\hline Zachodniopomorskie & 107,2 & 11,0 & 20,5 & 11,7 & 5,5 & 8,4 & 1,8 & 1,6 & 1,6 & 3,1 \\
\hline Polska & 99,4 & 10,4 & 16,3 & 13,7 & 5,1 & 7,0 & 2,1 & 1,3 & 1,8 & 2,9 \\
\hline
\end{tabular}

'Jelito grube C18-C21; ${ }^{2}$ Chłoniaki C82-C85+C96; ${ }^{3}$ Białaczki C91-C95

szacunków nie oczekuje się znaczących zmian w strukturze zachorowań i zgonów na nowotwory w 2012 roku.

Stały monitoring epidemiologii nowotworów złośliwych jest konieczny do obiektywnej oceny zagrożenia tym schorzeniem polskiej populacji. Za najskuteczniejsze narzędzie monitorowania zagrożeń chorobami onkologicznymi uważane są powszechnie rejestry nowotworowe. Rejestry nowotworowe istnieją w większości krajów Europy, przy czym działają w bardzo zróżnicowanym zakresie, począwszy od wybranych jednostek administracyjnych czy subpopulacji do populacji całych krajów włącznie.

Rejestr nowotworów działający w Polsce obejmuje całą populację Polski. Obecna organizacja rejestracji w Polsce (sieć 16 rozproszonych rejestrów) jest w trakcie przekształcania w nowoczesny system, którego najważniejszym elementem będzie wspólna, zintegrowana baza danych z elektronicznym dostępem do większej niż dotychczas liczby źródeł danych, spełniająca najwyższe standardy ich bezpieczeństwa [15]. Nowoczesny rejestr nowotworów złośliwych stanie się silnym i wszechstronnym narzędziem do mierzenia i monitorowania wskaźników zachorowalności i chorobowości w zakresie chorób nowotworowych, będących jednym z najpoważniejszych problemów zdrowia publicznego oraz systemu ochrony zdrowia w Polsce.

Dr n. med. Urszula Wojciechowska

Dr n. med. Joanna Didkowska

Krajowy Rejestr Nowotworów

Zakład Epidemiologii i Prewencji Nowotworów

Centrum Onkologii — Instytut im. Marii Skłodowskiej-Curie

ul. Roentgena 5, 02-781 Warszawa

e-mail:krn@coi.waw.pl

Przyjęto do druku: 22 stycznia 2013 r.

\section{Piśmiennictwo}

1. Wojciechowska U, Didkowska J, Zatoński W. Nowotwory złośliwe w Polsce w 2010 roku. Warszawa: Centrum Onkologii — Instytut im. Marii Skłodowskiej-Curie, 2012

2. Parkin DM, Whelan SL, Ferlay J i wsp. Cancer Incidence in Five Continents. Vol. VII. IARC Scientific Publications No. 143, Lyon 1997.

3. Sasieni PD, Shelton J, Ormiston-Smith N i wsp. What is the lifetime risk of developing cancer?: The effect of adjusting for multiple primaries. BJC 2011; doi: 10.1038/bjc.2011.250.

4. Esteve J, Benhamou E and Raymond L. Descriptive Epidemiology (IARC Scientific Publications No.128), Lyon 1994.

5. Clayton D, Schifflers E. Models for temporal variation in cancer rates. I: age-period and age-cohort models. Statistics in medicine, 1987; 6: 449-467.

6. GUS 2012 http://www.stat.gov.pl/gus/5840_13399_PLK_HTML.htm (dostęp z dnia 2 X 2012).

7. Kim HJ, Fay MP, Feuer EJ, Midthune DN. Permutation tests for joinpoint regression with applications to cancer rates. Stat Med 2000; 19: 335-351 (correction: 2001; 20: 655).

8. Bray F, Parkin DM. Evaluation of data quality in the cancer registry: Principles and methods. Part I: Comparability, validity and timeliness. EJC 2009; 45: 747-755.

9. Koszarowski T, Gadomska H, Wronkowski Z i wsp. Nowotwory złośliwe w Polsce w latach 1952-1982. Warszawa: Centrum Onkologii — Instytut im. Marii Skłodowskiej-Curie, 1987.

10. Wojciechowska, Didkowska J, ZatońskiW (red.). Rejestracja nowotworów złośliwych. Zasady i metody. Warszawa: Centrum Onkologii — Instytut im. Marii Skłodowskiej-Curie, 2007.

11. Zatoński W, Przewoźniak K, Sulkowska U i wsp. Palenie tytoniu w populacji mężczyzn i kobiet w Polsce w latach 1974-2004, Zeszyty Naukowe Ochrony Zdrowia. Zdrowie Publiczne i Zarządzanie, 7 (2), 2009, Kraków, s. 4-11.

12. Didkowska J, Mańczuk M, McNeill A i wsp. Lung cancer mortality at ages 35-54 in the European Union: ecological study of evolving tobacco epidemics. BMJ 2005; 23; 331: 189-191.

13. Wojciechowska U, Didkowska J, Zatoński W. Nowotwory złośliwe w Polsce w 2008 roku. Warszawa: Centrum Onkologii — Instytut im. Marii Skłodowskiej-Curie, 2010.

14. Didkowska J, Wojciechowska U. Epidemiologia nowotworów złośliwych narządów płciowych u kobiet w Polsce. Curr Gynecol Oncol 2012; 10 : 25-37.

15. Projekt pt. „Utworzenia pierwszej w Polsce informatycznej platformy naukowej do wymiany wiedzy o zagrożeniu nowotworami złośliwymi w Polsce" współfinansowany przez Program Operacyjny Innowacyjna Gospodarka pt. „Działanie 2.3 Inwestycje związane z rozwojem infrastruktury informatycznej nauki". 